\title{
El frau de l'alquimista a l'infern dantesc de Joan Pasqual i en la tradició medieval
}

\author{
Francesc J. Gómez \\ Universitat Autònoma de Barcelona \\ FrancescJosep.Gomez@uab.cat \\ http://orcid.org/OOOO-OOO3-O250-2277 \\ Received o6/o3/2015; accepted 26/o5/20I5 \\ DOI Io.7203/MCLM.2.6446
}

\section{The alchemist's fraud in Joan Pasqual's Dantesque hell and in medieval tradition}

Abstract

This article presents and analyses chapter XLVI from the Tractat de les penes particulars d'infern by Catalan franciscan friar Joan Pasqual, written soon after I436. This chapter, "Del cercle de l'alquímia”, includes an exemplum which is doubly significant: on the one hand, it documents the alchemic legend in the Plantagenets' court during the I4th and I $5^{\text {th centuries; }}$ on the other hand, and most importantly, it is a new testimony of two narrative motifs of Eastern origin: the fake alchemist and the king (Thompson, K.III.4; Tubach, 89), and the account-book of mistakes or fools (Thompson, J.I37I). After introducing the medieval witnesses of these motifs, the alchemic legend of Ramon Llull and king Edward of England, and Joan Pasqual in his historical context, the essay offers an edition of the Catalan text and a thorough comparative analysis with the more evident witnesses within the tradition: for the whole story, the Kitäb al-mukhtär fi kashf al-asrār (IX, 9) by Al-Jawbarī, the exemplum XX in the Libro del conde Lucanor by don Juan Manuel and the anonymous Libro del caballero Zifar, also Fèlix or Llibre de meravelles (VI, 36[4].47-68) by Ramon Llull for the motif of the alchemist and the king, and the novella LXXIV in the Novellino Borghini for the motif of the account-book of mistakes or fools. The conclusions of this analysis allow to trace the outline of a very useful stemma narrationum to discuss the position of Geoffrey Chaucer's The canon's yeoman's tale within the tradition.

KEYWORDS

Alchemy; exempla; brief forms; exemplum of the alchemist and the king; Joan Pasqual; Al-Jawbarī; Ramon Llull; Fèlix o Llibre de meravelles; Don Juan Manuel; El conde Lucanor; Libro del caballero Zifar; Novellino; Geoffey Chaucer; The canon's yeoman's tale.

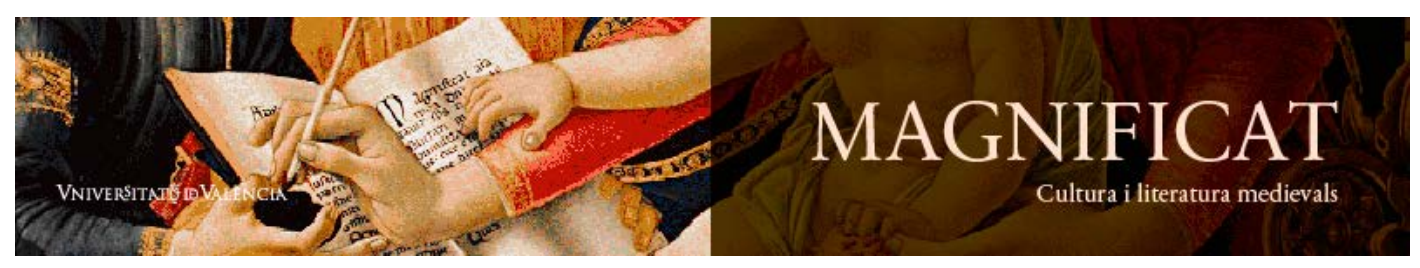

Magnificat Cultura i Literatura Medievals 2, 20I5, I59-196. http://ojs.uv.es/index.php/MCLM

ISSN $2386-8295$ 
RESUM

L'article presenta i analitza el capítol XLVI del Tractat de les penes particulars d’infern del franciscà català Joan Pasqual, escrit poc després de I 436. Aquest capítol “Del cercle de l’alquímia” conté un exemplum doblement significatiu: d'una banda, com a document de la llegenda alquímica de la cort dels Plantagenet als segles XIV i XV; de l'altra, i sobretot, com un nou testimoni de dos motius narratius d'origen oriental: el del fals alquimista i el rei (Thompson, K.III.4; Tubach, 89) i el del llibre dels folls (Thompson, J.I37I). Després de presentar els testimonis medievals d'aquests motius i la llegenda alquímica de Ramon Llull i el rei Eduard d'Anglaterra, com també la figura i el context històric de Joan Pasqual, l'estudi ofereix una edició íntegra del text català i en fa objecte d'una detallada anàlisi comparativa amb els testimonis més evidents de la tradició: el Kitāb al-mukhtārfì kaixf al-asrār (IX, 9) d'Al-Jawbarī, l'exemple XX del Libro del conde Lucanor de don Juan Manuel i l'anònim Libro del caballero Zifar per al conjunt de la narració, a més del Fèlix o Llibre de meravelles (VI, 36[4].47-68) de Ramon Llull per al motiu de l'alquimista i el rei, i de la novella LXXIV del Novellino Borghini per al motiu del llibre dels folls. Les conclusions d'aquesta anàlisi permeten d'esbossar un stemma narrationum molt útil per a discutir la posició de The canon's yeoman's tale de Geoffrey Chaucer dins el conjunt de la tradició.

PARAULES CLAU

Alquímia; exempla; formes breus; exemplum de l’alquimista i el rei; Joan Pasqual; Al-Jawbarī; Ramon Llull; Fèlix o Llibre de meravelles; Don Juan Manuel; El conde Lucanor, Libro del caballero Zifar; Novellino; Geoffey Chaucer; The canon's yeoman's tale.

Francesc J. Gómez, 20I5, “El frau de l’alquimista a l’infern dantesc de Joan Pasqual i en la tradició medieval”, Magnificat Cultura i Literatura Medievals 2, I59-196.

Projecte FFI2OI4-53O5O-C5-4-P finançat pel Ministeri d’Economia i Competitivitat

\section{TAULA DE CONTINGUTS}

I Tradició europea d'un conte oriental - I6I

2 El frau d'alquímia a l'infern dantesc de Joan Pasqual - 167

3 En la perspectiva de la tradició $-\mathrm{I} 7 \mathrm{I}$

3.I Anàlisi seqüencial - I72

3.I.I L'estafador i la víctima $(\$ \S 6-9)$ - I72

3.I.2 L'ingredient bàsic de l'opus alchemicum (\$

3.I.3 L'especier (\$ I2) - I77

3.I.4 La troballa de l'ingredient $(\S \mathrm{I} 3)-\mathrm{I} 78$

3.I.5 La demostració (\$ I 4$)-$ I79

3.I.6 La fugida amb el botí ( $(\mathrm{I} 5)-$ I8I

3.I.7 El llibre dels folls (§§ I6-I9) i algunes conclusions - I83

3.2 Marc narratiu illiçó moral - 186

4 Originalitat i tradició en The canon'syeoman's tale de Chaucer - I88

5 Cap a un stemma de la tradició - I9I

6 Obres citades - 194

6.I Remissió a les edicions de les obres més citades - 194

6.2 Totes les obres citades - 194 


\section{ə*⿻丷木}

\section{Tradició europea d'un conte oriental}

\section{E} 1 Motif-index of folk literature de Stith Thompson i l'Index exemplorum de Frederic C. Tubach enregistren diverses variants i testimonis d'un argument d'origen persa que féu fortuna en la literatura europea medieval: el d'un estafador que s'aprofita de la cobdícia i la insensatesa de la seva víctima per a ensarronar-la amb una presumpta demostració alquímica. ${ }^{1}$

La versió més antiga que se'n coneix és la que l'escriptor sirià generalment conegut com AlJawbarī inclogué pels volts de la tercera dècada del segle XIII (I222/32) en el seu Kitāb al-mukhtärfì kaixf al-asrär ('Recull de la revelació dels secrets' o 'dels secrets desvelats'), en un capítol dedicat a la fraudulència dels alquimistes (IX, 9; Höglmeier ed. 2006, r88-96 i 434-36). ${ }^{2}$ Al-Jawbarī ambienta l'estafa a Damasc al tercer quart del segle XII, atribuint-la a un persa de la remota província de Khorasan que s'aprofita de les ambicions del poderós soldà Abū-l-Q̨āim al-Malik al-'Ādil Nūrad-Dīn Maḥmūd ibn Zangī (II 47-74), en peu de guerra contra els croats. ${ }^{3}$ A més a més, Al-Jawbarī enllaça el final de la història amb una altra anècdota curiosa: la del "llibre dels folls" ${ }^{4}$ Perquè resulta que un home que porta un peculiar registre d'incauts l'ha encapçalat justament amb el nom del soldà Nūr-ad-Dīn. Quan el soldà el fa comparèixer davant seu i li’n demana el motiu, l'home li retreu la seva ingenuïtat davant les promeses de l'alquimista amb una breu resposta plena d'agudesa i enginy.

Aquests dos motius -l'estafa de l'alquimista (K.III.4) i el llibre dels folls (J.I37I) - gaudiren cadascun d'una vida independent en la tradició occidental. Una variant de l'estafa de l'alquimista és narrada molt sintèticament per Ramon Llull en el Fëlix o Llibre de meravelles (VI, 36[4] -47-68; Badia et al. ed. 2OII, I, 2I9-20), que n’és el testimoni europeu més antic (I288/89). Ja a la fi del segle XIV també l'explica, amb força més amplitud i originalitat, Geoffrey Chaucer en els Canterbury tales (VIII [G], vv. 972-I48I; Benson ed. 1988, 275-8I), concretament en la "Pars secunda" de The canon's yeoman's tale, atribuint l'estafa a un canonge regular que ven la fórmula o recepta de la

I. Thompson I955-58, no. K.III.4: "Pseudo-magic formula for making gold sold to king. Gold required for its manufacture carried off by manufacturer"; Tubach I98I [I969], I4-I5, no. 89: “Alchemist gets money for gold. An alchemist receives money from a king to whom he gives material he pretends to have turned into gold." Per a l'estudi comparatiu de la tradició cal remetre principalment a Marsan I974, 388-98; Serrano Reyes I996; Fradejas Lebrero 2 OoI.

2. Sobre la personalitat de l'autor i les variants del seu nom en la tradició manuscrita (Jamāl-ad-Dīn [Zayn-adDīn] ‘Abd-ar-Raḥ̄̄m ['Abd-ar-Raḥmān] ibn 'Umar ibn Abī-Bakr ad-Dimaixqī al-Jawbarī), vegeu Höglmeier ed. 2oo6, 3I-4O. El testimoni bàsic (Leiden, University Library, Or I9I) i el de control (Istanbul, Süleymaniye Kütüphanesi, Karaçelebizade 253) d'aquesta edició daten, respectivament, dels anys I3I4-I5 i I3I7-I8, i són probablement els més antics de la trentena de manuscrits que conserven el text íntegre del Kaixf al-asrār (Höglmeier ed. 20o6, 50-58). Cito el conte IX, 9 (Io segons la numeració d’altres manuscrits i edicions) en una versió catalana a cura d'Alba Vinyes Lasso, amb la supervisió de Tànit Assaf. N’he consultat igualment les dues traduccions franceses de René R. Khawam: la primera, reproduïda per Marsan (I974, 6I7-22), és feta a partir del testimoni de París, Bibliothèque Nationale de France, ms. 4640, ff. 43r-5or; la segona, dins la traducció íntegra del Kaixf al-asrār (Khawam trad. 1979-80, I, 214-27), es basa en quatre testimonis no especificats.

3. L'obra d'Al-Jawbarī ha estat considerada un testimoni sociològic de la vida marginal dels Banū Sāsān de Pèrsia; per al context del seu relat, vegeu Abrahams ı984; Höglmeier 2006, I7-25; López Pérez 2OıO-I3, I5-2i; Principe 2OI3, 49-5o.

4. Thompson 1955-58, no. J.r37I: "The account-book of mistakes. A king, hearing that a man keeps an account-book of people's mistakes asks to see about his own record. He reads that the king has made a mistake in trusting a certain sum of money to a servant. King: 'How if he comes back with it?' 'I shall cross off your name and put him down for making a mistake." 
transmutació alquímica a un capellà beneit. ${ }^{5}$ Entretant, just en les dècades centrals del segle XIV, també comença a forjar-se el corpus alquímic pseudolul-lià i la vària llegenda de Llull alquimista (Pereira 1987; 1989, 38-49), que requereix un breu comentari particular.

Aquesta llegenda, plenament configurada al segle XVI i molt difosa al XVII (Pereira I987, I5I-63; I989, 46-49), és el resultat de la combinació de dos motius originàriament independents: d'una banda, el del mestratge d'Arnau de Vilanova, suposadament determinant perquè Llull superés el seu escepticisme i esdevingués un adepte de l'alquímia mèdica, de vegades en relació amb un rei Robert identificable amb Robert d'Anjou; de l'altra, el de l'estada de Llull a Anglaterra, on hauria practicat la transmutació dels metalls en benefici d'un rei Eduard identificable, malgrat l'anacronia, amb Eduard III (Pereira I987, I46-47; I989, 38-45). El fonament bàsic d'aquest segon motiu és el colofó del Testamentum pseudolul-lià (I332) i alguna breu al-lusió en altres textos del mateix corpus; ${ }^{6}$ però, en la seva evolució o elaboració posterior, crec que s'hi pot reconèixer la influència del motiu oriental de l'alquimista i el rei, adaptat a un punt de vista occidental i, sobretot, favorable a l'alquimista, com a consell de prudència davant la cobdícia i la prepotència dels poderosos.

Aquesta influència potser no actua encara en aquells textos que es remunten a la primera fase del motiu i que descriuen una col-laboració entranyable i positiva entre Llull i el rei Eduard. Un testimoni tardà però molt eloqüent d'aquesta primera versió és el tractat De lapide philosophorum et de auro potabile, escrit a Pola pel metge Guglielmo Fabri de Dye i dedicat a l'antipapa Fèlix V (I43949): segons Fabri, el rei Eduard hauria cercat els secrets de l'alquímia viatjant d'incògnit, disfressat d'ermità, i hauria dispensat tan bona acollida a Ramon Llull, Arnau de Vilanova i John Dastin que fins i tot hauria volgut repartir el seu reialme entre ells; representa, per tant, un model per a la resta de sobirans. ${ }^{7}$

5. Vegeu-ne l'excel-lent traducció catalana de Victòria Gual (1998, 44-5-52) i els comentaris de Cooper 1996, 368-8I, i Collette-DiMarco 2005, 7I6-24.

6. Pereira I987, I46-47 nn. 8-IO. El primer text volgudament pseudolul.lià és el De secretis naturae seu de quinta essentia, de la segona meitat del segle XIV (Pereira I987, I49-5I; I989, II-2I), que atribueix a Llull el Testamentum i el conjunt de textos alquímics que s'hi relacionen, alguns dels quals potser deguts a un mateix autor (Pereira I989, 6-II). El Testamentum, compost a Londres i lliurat al rei Eduard III el I332 segons un colofó digne de crèdit, fou escrit en llatí i de seguida traduït al català probablement pel seu autor, un presumible metge mallorquí format a Montpeller, molt familiaritzat amb les obres de Ramon Llull i Arnau de Vilanova, i també practicant de l'alquímia a Nàpols (PereiraSpaggiari ed. I999, IX-XXIX, XXXIX-XLII). La proposta d'atribuir alguns d'aquests textos a un altre “mestre Ramon”, confós amb Ramon Llull per homonímia, i d'identificar-lo amb el dominicà convers Ramon de Tàrrega, processat per heretgia i mort el I37I, manca de fonament, malgrat la recent represa de Patai I994, I75-203; cf. Pereira I989, 20-2I; PereiraSpaggiari ed. I999, XXVII-XXIX. L'actitud permissiva, o fins la protecció i l'interès, que la cort anglesa solia dispensar als practicants de l'alquímia la convertí en un pol d'atracció d'alquimistes, sobretot durant el regnat d'Eduard III (I327-77); vegeu Pereira-Spaggiari ed. I999, XV-XIX; Crisciani 2002a, 225; Hughes 2OI2, esp. 32 i 9I-92; Principe 2OI3, 7 ${ }^{\mathrm{I}-73 .}$

7. Vegeu Pereira 1989, 42-43, i sobretot Crisciani ed. 2002b, esp. I46: “Quot labores sumpserit rex Angliae Odoardus, qui in habitu heremite pro hac arte circuivit orbem terrarum; et quomodo tractavit Arnaldum, Raymondum et Johannem de Testym, reperiuntur cronice laudabiles", i p. I64: "De principatu et prelatione veri philosophi non curant, quia habent quidquid desiderant, ut patet de Arnaldo, Raymondo et Johanne de Testym, cum quibus rex Odoardus, completo opere et inter eos diviso, voluit dividere regnum suum. Sed dixerunt regi quod regnare et philosophari essent duo incompatibilia." Per a col-locar l'origen d'aquesta versió abans de i335, com apuntaren els germans Carreras Artau (I972, 235-39) i ha desmentit Pereira (I987, I46 n. 5; I989, 40-4I), no solament caldria donar crèdit al Recueil des dames de Pierre de Brantôme (c. I540-I6I4), que cita com a font un comentari perdut del cànon De falsa moneta (Codex Iustiniani 9.24) escrit pel jurista Oldrado da Ponte, mort a Avinyó el I335 (Migliorino I98I), sinó que també caldria poder verificar quins elements del relat podrien derivar d'altres fonts implícites. Després d'al-ludir a la llegenda del pit cancerós, manllevada de Charles de Bouvelles, Brantôme continua: "Et, estant de retour de la terre sainte, où il avait fait voeu, s'en alla estudier à Paris, sous Arnaldus de Villanova, sçavant philosophe. Et y ayant fait son cours, se retira en Anglaterre, où le roy pour lors le reçut avec tous les bons recuilz du monde pour son grand sçavoir, et qu'il transmua plusieurs barres et d'estain, mesprisant ceste commune et triviale façon de transmuer le fer et le plomb en or, parce qu'il 
Una fase ulterior de la llegenda descriu, però, una relació profundament decebedora, com un reflex invertit del motiu de l'alquimista i el rei segons la narració d'Al-Jawbarī: Llull s'ofereix a proporcionar quantitats il-limitades d'or i argent al rei d’Anglaterra, amb la condició que els inverteixi exclusivament en un projecte de croada al servei de la cristiandat; però el rei manca al seu jurament i desvia el seu poderós exèrcit contra França. Pel volts de I 475 l'Elucidarium de l'italià Cristòfol de París, adepte de l'alquímia pseudolul-liana, invoca la decepció de Llull a la cort d'Eduard d'Anglaterra com a exemple que els alquimistes no han de confiar en els poderosos ni promoure l'obra de Déu mitjançant l'or alquímic. ${ }^{8}$ Però aquest motiu ja devia ésser molt difós al primer terç del segle XV, car un tractat sobre la transmutació dels metalls compost per mestre Jean Saulnier (o Saunier) el I $43^{2}$ hi afegeix nombroses innovacions: Llull hauria coincidit a la universitat de París amb el príncep Ricard d’Anglaterra i s’hauria incorporat a la seva cort quan aquest accedí al tron, però hauria comès l'error de revelar-li que coneixia el secret de la transmutació. El jove rei el confina dins el regne i, traint la seva promesa, envaeix França. ${ }^{9}$ Segons una breu al.lusió del tractat pseudolul.lià Experimenta (Pereira 1989, no. I.2I), Llull fins i tot fou empresonat i hagué de fugir (“Experimentum Decimum tertium Arnoldi de Villa Nova quod Neapoli nobis revelavit”): “Hoc operati sumus pro rege Anglico, qui finxit se contra Turcam pugnaturum, \& postea contra Regem Galliae pugnavit, meque incarceravit, \& tandem evasi. Caveas ergo tibi fili, ab his" (Manget ed. I7O2, I, 834a). Sense parlar de presó, és tanmateix més explícit el Testamentum Cremeri, sens dubte molt anterior a la seva difusió impresa. Aquest Cremer, presumpte abat de Westminster, conegué mestre Ramon a Itàlia, se’n féu deixeble i el pregà de traslladar-se i establir-se amb ell a Anglaterra,

sçavoit que plusieurs de son temps sçavoyent faire ceste besogne aussi bien que luy, qui sçavoit l'un et l'autre, mais il vouloit faire un par dessus les autres" (Carreras Artau I972, 236 n. 19).

8. Cit. Pereira I987, I 49 n. I9; I989, 45-46 n. 52: "Deus omnipotens plures alias liberationis vias habet et alchymicis opibus non eget. Quas si Raymundus Lullius Eduardo regi in immensa auri summa in illum finem subministravit, ut in Barbariam proficisceretur, et totum illum regnum ad religionem Christianam converteret, res tamen non ex voto successit, quamvis se Deo rem acceptam et gratam praestare putarit. Nam praefatus rex multorum navium classe Galliam appulit et illam sibi prius subiugare volebat, multumque sanguinis Christiani fudit, Raymundo vero se quamprimum domum redire Barbariam petitum promisit et plus auri conficere iussit. Raymundus autem super hac re multo animi dolore affectus et iratus ex Anglia se subduxit.”

9. Vegeu Pereira I989, 44 n. 42. Rodríguez Guerrero (2009, 35 n. I7) n’ha anunciat una pròxima edició a cura de Sylvain Matton i n'ha enumerat tres manuscrits més del segle XV. El text és transcrit per Corbett I951, I53-54, a partir del ms. Orléans, Bibliothèque municipale 29I, copiat el $5_{5} \mathrm{I} 6$ per Pierre Bureteau, ff. 57 r-68v ("Cy commance une doctrine de philosophie laquelle maistre Jehan Saulnier bailla a son filz sur la transmutation des metaulx"), esp. ff. $57^{\mathrm{V}-58 \mathrm{r}: ~ " M o n ~}$ filz, je te dis et faictz assavoir que fut et n'a pas long temps que un sage clerc appele maistre Raymond qui estoit du pays de France, c'est assavoir de l'isle de Maillezais, et fut maistre en la ville de Paris tant es ars que en la faculte de theologie. Si estudia tant qu'il sceut la parfaicte et vray science de philosophie moralle et naturelle. Or fut ainsy qu'il fut longtemps estudiant le filz du roy d'Angleterre. Lequel maistre Raymond aymoit tresfort et estoit forment son famillier comme escolliers qui ont demoure ensemble en leur jeunesse en ung hostel et apres que ledit filz nomme Richard sen fut alle en Angleterre et qu'il en fut roy maistre Raymond s'en alla vers icelluy roy. Et fut ledit maistre Raymond si pouvrement conseille qu'il dist a se jeune roy qu'il scavoit la transmutation des metaulx, c'est assavoir, comme on les transmuoit en fin or en fin argent et pria au roy d'angleterre qu'il mist une grosse armee de gens et pria au roy d'Angleterre qu'il mist une grosse armee de [sic] guerre pour aller en Sarrazinesive contre les mescreans et infidelles de la foy de Jhesu Crist et qu'il ne se sociast point d'argent car il luy feroit tant d'or et d'argent qu'il pourroit payer cent mille hommes pour sept ans si luy promist faire ung million de fin or sans ce qu'il luy falloit pour payer ses gens d'armes. Quant le roy oyt ce qu'il fut fort joyeulx et luy promist de faire ce que maistre Raymond luy avoit dit et requis dilligemment et commanda audit Raymond a besongner ce qu'il fist. Ce nonobstant le roy le gardoit tousjours secretement comme prisonnier en sa terre sans point partir de son royaulme. Quant l'armee du roy fut preste et bien en point ledit roy fist tourner ladite armee vers le pays de France en lieu d'aller en Sarrazinesive, donc grans maulx en sont advenus en ce royaulme de France et sont tous les jours soubz umbre de la querelle que les angloys croyent avoir en France. Et pour ce mon filz je te prie de rechef et expressement te commande et enjoinctes que ceste science tu vueilles bien tenir secrette pour les grans inconvenients que sen pourroient ensuivre." 
on el freqüentà durant dos anys fins a l'absoluta consecució de l'opus alchemicum. Llavors el presentà al rei Eduard (cit. Pereira I987, I47-I48 n. I2; I989, 39 n. II):

Posteaquam hunc virum egregium in conspectu inclitissimi Regis Edovardi deduxi, a quo merita dignitate recipitur et omni humanitate tractatur, ibique multis promissis, pactis, conditionibusque a rege inductus, erat contentus Regem pro missione divina sua arte divitem facere. Hac solummodo conditione, ut res in propria persona adversus Turcas, inimicos Dei, bellum gereret impenderetque super domum Domini, minimeque in superbia aut bello gerendo adversus Christianos: sed (proh dolor) hoc promissum erat irritum a rege violatumque, tum ille vir prius in spiritibus penetralibusque cordis sui afflictus hinc trans mare lamentabili miserabilique more aufugit, quod cor meum urit non mediocriter.

En un moment imprecisable de la seva evolució, la llegenda es vinculà també amb l'encunyament del noble de nau -moneda d'or, introduïda per Eduard III el I344, que presentava l'efígie del rei Eduard (després Ricard II i successors), espasa i escut en mà, a bord d'un vaixell-i, més tard, amb el noble de rosa -que començà a encunyar-se el I464. ${ }^{\circ}$ En un Nomenclator publicat a París el I555, l'antiquari Robert Constantine testimonia la llegenda d'una emissió de moneda de puríssim or alquímic coneguda com a "noble de Ramon"."

La llegenda de Llull representa, finalment, un exemple de cautela per als practicants de la crisopea, i també un "reflex invertit” del motiu tradicional: l'estafa de l'alquimista. Certament, tant la recerca com la pràctica de l'alquímia es desenvolupen històricament en un context arriscat, en què els alquimistes s'exposen a greus perills, i els incauts a l'engany (Crisciani 2002a, 223-26; 2002b, 8I-84). Per això, els detractors de l'alquímia -medievals i moderns, i amb una vis còmica més o menys accentuada-, degueren recórrer sovint a l'exemplum del fals alquimista. Ho fa, per exemple, Erasme de Rotterdam en els colloquia "Alcumistica" i "Ptochologia" (I524), potser influïts, directament o indirecta, per Chaucer (Collette-DiMarco 2005, 734-35). I, entre molts d'altres, resulta significatiu l'extens repertori de fraus alquímics que Athanasius Kircher enumera en el capítol VIII de la seva De lapide philosophorum dissertatio (Manget ed. I7O2, I, 54-82), entre els quals recull una veritable síntesi argumental del motiu divulgat per Al-Jawbarī i els altres testimonis de la tradició:

Sunt etiam qui certa scriniola diversis pulveribus unà cum pulvere auri, \& argenti mixtis implent, quibus \& ad fraudem tegendam exotica herbarum, mineraliumque nomina imponunt: postea adeunt unum ex iis, quem norunt Chymicis deditum, eidem ingens magnae Artis secretum paucis nummis emendum exponunt, experimento artis aurificae se veritatem docturos pollicentur, dummodo expensae in auro conficiendo rependantur; \& si veritatem rei non deprehenderint, omnia sua confiscationi se subjecturum promittunt. Jubent itaque emere pulverem auri, jam per aquam regiam in substantiam morbidam, \& friabilem resolutum: opus auspicantur, \& cum admiratione adstantis educunt aurum purissimum. Unde spectator tanti boni acquisitione audacior factus, plus aequo credulus, \& simplicioris animi homo, pro arte quantum velit \& libuerit rogat; impostor ait

Io. Vegeu Pereira 1989, 4 O n. I6, i cf. Maugin de Richebourg I74O-54 [1672-73], LX-LXI n. I: "Edouard ayant appris l'évasion de Raymond Lulle, le fit poursuivre, mais inutilement. Pour conserver à la Postérité la mémoire de cet évenement, Edouard fit battre une monoye, qui s'appelle Rosa nobilis, \& que les Curieux conservent encorre aujourd'hui comme une Médaille précieuse; sur laquelle on voit empreinte une Rose audessus d'une Barque, qui fait voile \& s'éloigne à force de rames". També se’n fa ressò Nicolas Lenglet Du Fresnoy en la seva Histoire de la philosophie hermétique I, 44-184; 2, 6-IO, i 3, 2IO-24 (Pereira I989, 39 n. Iо).

II. Transmet la notícia Duval I56I, 5: "in arce Londini, iussu Regis probatissimum aurum confecisse, mihique genus numi ostensum est, quod adhuc appellant Nobile Raymundi, auri uidelicet puri, \& obrizi, summeque indicaturae". Vegeu Pereira 1989, 47 n. 57; Hughes 2012, 92. 
tantum \& tantum, acceptaque pecunia se protinus subducit; alter desiderio nimio communicatae artis percitus, dum pulverem illum exotico quodam, \& monstruoso nomine baptizatum, ardentius quaerit, nec apud Pharmacopeos, aut Herbarios materiam reperit, tandem se elusum crumenta [crumena?], \& nummis vacuum reperit. (Manget ed. I702, I, 8ob)

Kircher acumula notícies de testimonis llatins, hebreus i àrabs, però, malauradament, d'aquests darrers s'estima més no parlar-ne: “Innumera hoc loco ex Arabum solennibus fraudibus adducere possem, quae passim in eorum libris de mineralibus Naturae reperiuntur, \& de aurificio inseruntur. Verùm cum indigna sint, quae referantur, silentio supprimenda duxi” (Manget ed. I7O2, I, 8га).

Fins aquí hem enumerat els principals testimonis occidentals de l'estafa de l'alquimista que només recullen el primer motiu de la història, sense el corol-lari del llibre dels folls. Ara ens toca de constatar el cas contrari. Els primers testimonis independents del llibre dels folls -segon motiu de la versió extensa del conte de l'alquimista i el rei- són italians, i el més fidel a la versió originària és la novella LXXIV del Libro di novelle et di bel parlar gentile, publicat a cura de Vincenzo Borghini (Firenze, Giunti, I572; Lo Nigro ed. I963, 335). Aquesta novella manca en la primera edició cinccentista de la col-lecció, Le ciento novelle antike (Bologna, I525), però es remunta molt probablement a un testimoni de la segona dècada del segle XIV (Lo Nigro ed. I963, 33I). En la versió del Novellino Borghini l'estafa s'atribueix encara a un alquimista. En canvi, en dos testimonis famosos de final del segle Xv ha estat el cortesà alemany Teodoric qui ha ensarronat el rei de Nàpols, Alfons el Magnànim, escapant-se amb una gran suma destinada a la compra de cavalls: així ho recullen el no. 6 dels Motti e facezie del Piovano Arlotto (Folena ed. I953, I8-20) i el no. 343 dels Detti piacevoli d'Angelo Poliziano (Zanato ed. 1983, IOI). ${ }^{.2}$ En altres versions, l'estafador ha estat un correu del rei Eduard d'Anglaterra que s'ha escapat amb els diners destinats a una ambaixada a Roma, tal com expliquen el mateix Poliziano en el no. 294 dels Detti piacevoli (Zanato ed. I983, 94) i el no. I9o del recull anònim de Facezie e motti (Papanti ed. I968 [I874], III). Moltes altres variants d'aquest motiu circularen també en la literatura castellana de l'edat moderna (Fradejas Lebrero 2OOI, III-I2 i II8-28; Rodríguez Guerrero 2009, 36).

Els testimonis de la transmissió conjunta de tots dos motius, com en la versió d'Al-Jawbarī, es reduïen fins avui a dos importants documents castellans de la primera meitat del segle XIV. Dels primers anys o, més probablement, del segon quart d'aquest segle data el Libro del caballero Zifar, d'autor anònim, que narra la falsa alquímia d'un cavaller estranger, fill de barber, i la nècia cobdícia d'un rei moro, a propòsit "Del consejo que dio el infante Roboan al enperador de Trigrida sobre vn fisico" (IV, 28; González ed. I983, 4OI-406). ${ }^{13}$ Sens dubte anterior a I335 és l'exemple XX d'El conde Lucanor de don Juan Manuel, en què Patronio explica el mal recapte d'un rei enganyat per un golfín disfressat d'alquimista, i ho fa també, justament, per aconsellar el comte Lucanor sobre una proposta d'inversió que li promet el deu per u del capital inicial (Serés ed. I994, 8I-85 i 366-368). ${ }^{\text {I4 }}$

Avui, però, cal afegir a l'inventari de testimonis de la versió extensa un nou text català de mitjan segle XV: el capítol XLVI del Tractat de les penes particulars d'infern del teòleg franciscà

I2. Aquest detto pertany a la darrera fase de redacció (I480-82) del "Bel libretto" (I477-82) de Poliziano, en la qual féu ús d'un recull d'anèdotes atribuïdes a Arlotto que es difongué pels volts de I478, abans de la darrera versió dels Motti e facezie (c. I488); vegeu Folena I953, XV; Zanato I983, 8-9 i ı2, i també Wesselski I9IO, I, I8I-86; I929, 290.

I3. La identificació hipotètica de l'autor amb el protagonista de l'anècdota prologal -el viatge a Roma, per a guanyar el jubileu de ı3оo, de Ferrán Martínez, ardiaca de Madrid a l'església de Toledo, documentat com a escrivà dels reis Alfons X i Sanç IV de Castella fins a I295- gaudia del consens de la crítica (González ed. I983, 20-23) fins que ha estat qüestionada per Cacho Blecua (I996, 57-68, esp. 62) amb una nova proposta de datació entre juny de I32I i I350. L'origen oriental de l'exemple de l'alquimista fou assenyalat per Wagner 1903, 88-89.

I4. Fou precisament a propòsit d'aquest exemple que Adolphe de Puybusque (I854, 277) assenyalà l'origen persa del motiu, després recollit per Devoto (1972, 404-405). 
Joan Pasqual (Gómez 2OI3b, 420-22 i 543-53). Entre les nombroses peculiaritats d'aquest nou testimoni, una de molt remarcable és el context en què s'insereix: un tractat de divulgació teològica sobre les penes de l'infern, encara que compost principalment a partir de l'Inferno de Dante i de la primera redacció del Comentum de Pietro Alighieri, en combinació amb altres fonts més habituals en l'utillatge d'un predicador, com ara la tercera redacció del De fabulis poetarum o Ovidius moralizatus de Pierre Bersuire, o com el De miseria humanae conditionis d'Innocenci III (Gómez 2005, 2OI3a, 20I3b, 20I5). Recorrent al motiu tradicional del fals alquimista, el teòleg completa la informació que li dicta la glossa de Pietro Alighieri a propòsit de la desena bolgia dantesca, la dels falsificadors de metalls (Inf. XXIX, 4O-I2O), i descriu un "cercle de l'alquímia” en el qual són punits tant Griffolino d'Arezzo i Capocchio da Siena com el fals alquimista estafador del rei; un rei que Joan Pasqual situa precisament a Anglaterra, en relació amb la llegenda alquímica de Llull i de la dinastia Plantagenet als segles XIV i XV.

L’exhumació d'un nou testimoni de la versió extensa, íntegrament comparable amb els relats del Kaixfal-asrār, del Lucanor i del Zifar, i també parcialment amb els principals testimonis independents dels dos motius que la integren, projecta nova llum sobre el conjunt de la tradició.

Un primer estudi comparatiu d'aquests textos -sense incloure, però, el conte de Chaucer ni la tradició independent del llibre dels folls- fou pulcrament abordat per Rameline Marsan (I974), que suggerí diversos graus de parentiu entre els testimonis hispànics i l’àrab: més immediata o directa la del Lucanor que no pas la del Zifar, i del tot indirecta la del Fèlix. ${ }^{5}$ D’altra banda, els estudis sobre Chaucer, que fins fa poc només assenyalaven el precedent de Ramon Llull (Babcock Folch-Pi I967; Cooper I996, 37 I-72) i el context general de la literatura alquímica (Duncan I968, Linden I996), ara afegeixen a Llull els dos anàlegs castellans del XIV i al-ludeixen a un inconcret origen àrab, sense mencionar, però, l'antecedent d'Al-Jawbarī ni l'estudi de Marsan (Serrano Reyes I996, 25I-368; Collette-DiMarco 2005, 73-34). Privada d'aquesta perspectiva, una anàlisi comparativa molt minuciosa arriba a concloure, potser no gaire encertadament, que el Zifar sigui font del Lucanor, que el Lucanor hagi exercit influència sobre The canon's yeoman's tale i que el Fèlix en sigui un anàleg més allunyat (Serrano Reyes I996, 26I-73, 368). S'imposa, doncs, una revisió del conjunt de la tradició, que inclogui tant els testimonis del llibre dels folls (Fradejas Lebrero 2OOI) com els antecedents del motiu oriental (López Pérez 2OIO-I3).

En el marc d'aquesta discussió, Joan Pasqual ens ofereix un nou terme de comparació molt valuós per a discernir millor el parentiu entre els testimonis i les línies principals de la tradició. És per això que, després d'esbossar tot seguit un breu perfil biogràfic de l'autor i alguns trets remarcables de la seva obra, proposaré una lectura del capítol XLVI del Tractat de les penes particulars dinfern a la llum dels principals testimonis del conte dels fals alquimista i el rei. En el curs d'aquesta lectura es dibuixaran algunes possibles agrupacions, com ara la del Fèlix i el Novellino Borghini; s’intuirà la presència d'un antecedent comú si més no als tres testimonis hispànics de la versió extensa, i, fins i tot, es constatarà l'existència d'una afinitat particular entre les versions del Zifar i de Joan Pasqual. Albirarem, per tant, un panorama més extens, amb testimonis perduts potser en àrab, llatí i/o llengües vulgars. Per al conte de Chaucer, el més innovador del conjunt, podrem remetre encara a l'estudi detallat de Serrano Reyes, però evitarem la temptació d'emparentar directament The canon's

I5. Marsan (I974) assenyala la probable existència d'altres fonts orientals anteriors a Al-Jawbarī (p. 389: “Certes le sujet ne devait pas être original, pas plus que la majeure partie des contes et récits de ce livre”) i la possibilitat d'alguna altra redacció (àrab?) com a model del Fèlix (p. 39I: "Des traits communs subsistent. Cependant, R. Llull connaissait à n'en point douter une rédaction différente”); quant al Zifar, considera que l'originalitat amb què l'autor adapta les seves fonts no permet discernir si deriva directament d'Al-Jawbarī o d'una font comuna (p. 392: "Prendre parti ne paraît guère possible"); en canvi, considera que el Lucanor no admet cap mena de dubte (p. 393: "Il suit fidèlement le texte d'AlJawbari et n'est aucunement une composition originale"). 
yeoman's tale amb cap dels membres coneguts d'aquesta família literària.

\section{El frau d'alquímia a l’infern dantesc de Joan Pasqual}

E franciscà Joan Pasqual mereix un lloc remarcable en la història de la cultura medieval com a autor d'una extraordinària summa de novissimis en català dividida en dos volums. El primer, titulat Llibre o Summa de beatitud, fou dedicat el I 436 a Joan Llull i Gualbes, conseller en cap de la ciutat de Barcelona, mitjançant un pròleg que definia clarament les dues parts del projecte i la seva intenció de divulgar entre els laics cultes la veritat teològica sobre l'altre món a fi de combatre l'escepticisme. Res no feia preveure que el segon volum d'aquesta obra, titulat Llibre o Summa de pena, es completaria amb un apèndix o Tractat de les penes particulars d'infern les fonts del qual no són pas teològiques, sinó poètiques: l'Inferno de Dante, la primera redacció del Comentum de Pietro Alighieri i la tercera redacció del llibre XV del Reductorium morale de Pierre Bersuire, titulat De fabulis poetarum, però més conegut com Ovidius moralizatus. Si, d'una banda, el recurs a aquest repertori mitogràfic per a predicadors ens autoritza a comptar Joan Pasqual entre els epígons més destacats dels classicizing friars (Smalley 1960), l'ús constant de la Commedia i del Comentum en un context d'alta divulgació teològica el converteix en un del testimonis més rellevants de la fortuna dantesca en el conjunt de la literatura medieval europea, atès que una iniciativa com la de Pasqual hauria semblat excepcional fins i tot a Itàlia, on la Commedia ja havia arribat a incorporar-se al repertori d'autoritats de la predicació, especialment franciscana (Gómez 2OI3b, I37-I59).

Encara són escasses, però, les dades que ens ajuden a perfilar-ne la biografia (Gómez 2orzb, I-25 i 794-797). Joan Pasqual degué néixer cap a I388/90 a Castelló d’Empúries, on prengué l’hàbit franciscà pels volts de I405. Més endavant residí i estudià al convent de Girona, on rebé els quatre ordes menors o acolitat el 28 de març de I4II, el sotsdiaconat el 24 de setembre de I4I2 i el diaconat el I8 de març de I4I3; poc després es degué ordenar prevere, però manca el document. Entre el 27 de febrer de I43i i el I3 d'octubre de I436 consta al monestir de Sant Francesc de Barcelona en l'ofici de procurator, economus et actor conventus. Joan Pasqual no s'intitula mestre en teologia ni en els documents d'aquest període ni en el pròleg del Llibre de beatitud, de I436; sí que ho fa, en canvi, en el breu preàmbul del Llibre de pena, no datat. En l'interval entre aquestes dues obres Pasqual no solament accedí segurament a la laurea magisterü -no sabem en quines circumstàncies-, sinó que també compongué una altra obra Dels deu manaments, avui perduda, i s’adonà de la possibilitat d'implicar la Commedia de Dante en la seva pròpia summa d'escatologia per a laics. Molt probablement no arribà mai a escriure una tercera obra sobre el purgatori que no era prevista en el pròleg de $\mathrm{I} 436$, però que ell mateix anuncia -sens dubte induït pel model del secondo regno dantesc- just abans d'emprendre el Tractat de les penes particulars d'infern. La darrera notícia que en tenim és que el 29 de març de I450, Diumenge de Rams, mestre Joan Pasqual predicà a la Seu de Girona un sermó en el qual publicà les solucions d'una disputa mantinguda dies abans amb els jueus de l'aljama, en presència de Bernat Joan de Cabrera, comte de Mòdica, i que prèviament havia instat els jurats de la ciutat a obligar els jueus a assistir-hi.

El Llibre de pena consta de tres parts principals (Gómez 20I3b, 65-78). Les dues primeres, que formen pròpiament la Summa de pena, es basen en fonts teològiques estrictes i s'ocupen, respectivament, de la naturalesa del pecat o reatus culpae i dels aspectes de la pena o reatus poenae que són generals i comuns a tots els damnats. Les penes corresponents a cada espècie de pecat són la matèria, en canvi, de la tercera part, el Tractat de les penes particulars d'infern, en què el teòleg assumeix com a pròpia l'ordenació moral de l'Inferno de Dante segons l'exposició del Comentum de Pietro Alighieri (Gómez 20I3b, 83-IIо). Malgrat algunes discrepàncies de criteri, 
Joan Pasqual degué apreciar especialment la claredat sistemàtica i la consistència teològica de la construcció dantesca, capaç de reduir la complexa multiplicitat de la culpa i de la pena a una estructura ordenada, i de funcionar alhora com un recurs mnemotècnic o imatge de la memòria, com han remarcat Frances Yates (I966, IO4) i Carlo Delcorno (I983, 4). Atesa la dimensió poètica i fabulosa de l'Inferno dantesc, Joan Pasqual va decidir també de dedicar una secció prèvia, titulada "De las penas comunas segons los poetas", a exposar al-legòricament la geografia i els personatges infernals de la mitologia clàssica, acudint a un autèntic manual de mitologia moralitzada per a ús de predicadors com el De fabulis poetarum de Pierre Bersuire.

En el conjunt de la seva obra teològica, Joan Pasqual fa un ús molt moderat, fins i tot escàs, dels recursos didàctics de la predicació popular, com ara les figurae, les similitudines i els exempla. No obstant això, el predomini de la temàtica moral en el Tractat de les penes particulars d'infern, així com la dimensió literària de les seves fonts, l’aproximen excepcionalment a les tècniques representatives i narratives de la predicació. Precisament, Joan Pasqual construí la secció preliminar "De las penas comunas segons los poetas" a partir d'una d'aquestes figurae o imatges: la imago Plutonis que Pierre Bersuire moralitza en el capítol autònom De formis figurisque deorum, introductori al repertori de faules de l'Ovidius moralizatus (Gómez 2013b, I6o-74).

Un altre indici de confiança en aquesta tècnica se'ns ofereix en l'adaptació teològica de Geríon i dels dos cercles més profunds de l'Inferno dantesc. Com és sabut, aquests dos cercles inferiors acullen dos tipus de frau: el primer, que no implica un abús de cap relació de fidelitat, correspon a alguna de les deu espècies punides a les deu bolge del cercle vuitè o "Malebolge", mentre que l'altre, que transgredeix algun vincle de fidelitat, correspon a alguna de les quatre espècies de la traïció del cercle novè. Dante i Virgili davallen en aquest abisme de fraudulència sobre el llom de Geríon, el monstre que Dante presenta com una "sozza imagine di froda" (Inf. XVII, 7), i que Pasqual tractarà, efectivament, com una imago fraudis perfectament anàloga a les imagines mitogràfiques de Pierre Bersuire. Aprofitant que Pietro Alighieri el descriu com un monstre triforme -cara d'home, cos de serp i cua d'escorpí- i que l'interpreta com una tripartició de les espècies del frau, el teòleg no solament assumeix literalment aquesta interpretació, sinó que també adopta aquesta tripartició com a criteri ordenador de totes les penes de frau, incloent-hi els traïdors. ${ }^{16}$ L'aplicació d'aquest esquema comporta una profunda reordenació dels materials i de l'estructura que proporcionen l'Inferno i el Comentum: Joan Pasqual prescindeix de les bolge dantesques, assigna un cercle propi a cada espècie de frau i els reordena segons un nou criteri classificatori (Gómez 2OI3a i 2OI5). Un d’aquests cercles és el que correspon a la desena bolgia dantesca: la dels falsificadors de metalls i alquimistes.

Pel que fa a l'ús d'exempla, Joan Pasqual treu bon profit de l'ampli repertori que li proporcionen tant els mites dantescos i ovidians, exposats al-legòricament per Pietro Alighieri i Pierre Bersuire, com les referències històriques i contemporànies de la Commedia, que el Comentum aclareix i contextualitza, i que sovint posseeixen un gran valor narratiu, intel-lectual i, sobretot, moral. Al marge d'aquestes fonts, però, Joan Pasqual només explica dos exempla morals, de font encara no

I6. Per a l'obra de Joan Pasqual i per als fragments que manlleva del Comentum de Pietro Alighieri, cito sempre els textos establerts per Gómez 20I3b, 297-434 i 679-754, respectivament. Vegeu Tractat de les penes particulars d'infern XLI, §§ I i 4-7: "De la altra spècia de malícia cové tractar, que és frau. [...] Dant afigura lo frau a Gerion [...]. Aquest Gerion era dit haver tres còssors per ço cum havia tres regnas o per ço cum frau és divís en dit, cosa e fet (car tot frau o és fet en paraula o en la cosa o en obra). E per ço era finyit ésser en part home, en part stel-lió serpent, en part scorpió. En ço que lo frau és comès en paraula és dit home, car parlar solament pertany al home. És comès lo frau en dit o per alcavotaria o per adulació o per scisma o per mal consell. [...] En ço que lo frau és comès en la cosa és dit stel-lió serpent [...]: axí diversos fraus són fets en les coses, axí cum en las mercaderies, symonias, ypocrisias, divinacions. En ço que lo frau és comès per fet és dit scorpió, lo qual dóna lesió, axí cum són barateries, furts, ledornicis, traÿdors.” 
identificada: un de molt breu, sobre l'obsessió de l'avar, sense paral-lels coneguts, ${ }^{17}$ i la seva versió "anglesa" del conte oriental de l'alquimista i el rei, inserit òbviament en l'exposició del cercle de l'alquímia:

[XLVI.] Del frau fet en la cosa. E primerament, del cercle de la alquímia

Inquirit dels fraus fets en dit o en paraula (entre los quals podem posar, segons damont dit és [XLIV, $\S 37$, los perjurs, axí cum la muller de Farahó e Symon), havem pertractar dels fraus fets en la cosa, axí cum és en falcificar les mercaderies en quantitat o en qualitat o en sustància, de las quals havem parlat en la Summa dels X manaments. [2] E perquè la alquímia és comunament frau en argent, aur o altra mena, per ço en lo present cercle la alquímia és punida segons l'acte, ço és en ardent foch bollints, ab demonis insuflants al foch, axí cum los alquimistas treballen de nit e de die fabricar ab vexells de terra, e bullen, e quant més procehexen en dies, tant major ardor han e menys atquirixen, axí com fan aquells qui-s graten cum han scàbia, que cum han començat gratar no se’n poden lexar e quant més graten més desigen gratar sens fi, axí cum diu Dant, libro Inferni, capitulo ХХVIIII ${ }^{\circ}$ [vv. 67-90]. [3] Entre los quals pose Dant mestre Grifolí de Arici, cremat a Cena per lo inquisidor a instància del bisbe de la ciutat per ço cum Arbre, fill del dit bisbe, havia decebut en peccúnia, prometent-li que li ensenyaria de volar per invocació diabolical, axí cum féu aquell Dàdalus del qual damont havem parlat [XLI, § Io]. [4] Axí mateix entre aquests és Capochi, florentí alquimiayre, cremat a Cena. [5] E molts són ja en aquest cercle, e en lo present disposts, car tal mal és la alquímia que, pux una vegada algú és dins l'art, nunqua se’n hix ne·s fa apòstata de la art.

[6] Entre aquests és aquell mercader de Sibilla lo qual se abaté, e pux en Portogal se vestí de grans robes e prengué ab si tres scuders; e, sabent que lo rey de Anglaterra era molt afectat a alquímia, lo mercader prengué $\mathrm{c}$ dubles e féu-ne puls, e posà la puls en I saquet de aluda, e passà ab los scuders, açò ignorants, en Anglaterra. [7] E cum fou a Londres bé encavalcat, posà en un gran hostal. E s'endemà que fou arribat, dix al hostaler si havia a Londres algú qui fos famós alquimiayre, dient que ell era partit de la sua terra per sercar si trobare algun qui fos major alquimiayre que ell; e l'ostaler li respòs que lo rey era molt affectat en alquímia, emperò que no·n trobava algun. [8] Lavors l'ostaler secretament anà al rey e dix-li: "Senyor, bona nova! En lo meu hostal posa lo major alquimiayre del món; e apar-ho, car va bé e noblement vestit e encavalcat ab la sua companyia; e va sercant lo món si trobarà major d'ell en fer alquímia”. [9] De açò lo rey hagué gran plaser, e tramès lo seu secretari a ell; e lo mercader mudà de robes e vingué devant lo rey. E dix-li de un era; respòs que era spanyol. Dix-li un anave; respòs que volia sercar si trobara millor alquimiayre que ell. Lavors lo rey pregà'l que no posàs al hostal: féu-li donar sol-lempne posada, e ell lo féu bé pensar de viandes e de vins, e féu-li nobles vestadures. [ı] Finalment lo rey li dix quina alquímia sabia fer; respòs que fin aur. Pregà'l lo rey que ell vehés la speriència; respòs lo mercader: "Son content. Hajam I a cambra secreta, que no y sia sinó vós e jo e lo secretari, e hajau-me creols e manxes per buffar e carbó, e hajau soffre e argent viu e tal púlvora", anomenant-la de nom innot. Lo secretari secretament per tots los speciers serquen la púlvora, e no la troba, ne lo nom era trobat en medicina, ne encare en lo Catolicon ne en lo Papias. Lo rey stava molt torbat cum no·n trobaven. [II] Dehia lo mercader: "Bé és fortuna que en aquesta terra no·s tròpia aquesta púlvora! En la mia terra n’à tanta que és menyspreada, que·n carregaria hom $x$ naus; e per valura de tres sous podem fer I gran carrell d'aur. Emperò és ignota la sua virtut per los hòmens de la mia terra, car algú no crehech que la sàpia sinó jo. E sens aquella lo fin aur no·s pot fer”. Altra vegada lo rey fa sercar per los speciers si-n trobarien,

I7. Tractat de les penes particulars d'infern XXIII, § I6: “Axí cum aquell avariciós que, cum la muller li hagués dit que ell ab ella se havien menjat I gros capó, de dolor de tanta despesa tostemps dehia en son cor: ‘Tot!, tot!, tot!', en tant que tant pres en la sua fantasia que tot lo capó era menjat, que tornà infirm e foll, que de la sua bocha ne del seu enteniment no·s podia partir aquest vocable, 'tot!, tot!', ne dehia alra, quant lo interrogaven, sinó 'tot!'. E crech que en infern, en lo cercle de la avarícia, tostemps romandrà en lo seu enteniment lo menjar de tot lo capó. E aprés que serà ressuscitat, per ventura dirà tostemps: ‘Tot!, tot!', etc.” 
e no.n troben.

[I2] Dementretant, secretament lo mercader pres la aluda del aur pulverizat e aportà'l a I specier vell pobre qui tenia los pots vàcuus. E dix-li: "Jo he compassió de vós e de la vostra pobresa. Lo secretari del rey va sercant aquesta púlvora que jo tench e no·n troba en algú specier. Jo, axí matex, no vull dir que jo n’age, car hauria-la a donar al rey. Jatsia que no val I sou, més ham que vós ne hajau de aquesta IIII $\mathrm{o}$ V sous de tota. Per què preneu-la, e stau avisat que, quant lo secretari vos dirà si haveu tal púlvora, digau que hoc, e feu-vos-en pagar v sous e donau-le-y ab la aluda tota". Lo specier pobrellet hagué gran goig perquè gonyàs alguna cosa. Fóu-li’n gràcias, pren la aluda, stuge-la, e té a ment quant vindria lo secretari.

[r3] Cum lo mercader fos ab lo rey, dix-li: "Senyor, jo ací no fas res. Pus que no trobam de la púlvora, anar-me’n é”. Lavors lo rey dix al secretari si havia bé sercat. Respòs: "Senyor, no és specier en Londres qui sia de afers que jo no hage sercat". Respòs lo mercader: "Gordau que tals púlvoras més stan en speciers antichs e pobres que en altres; sercats-los”. Lavors lo secretari sercà per tots los speciers pobres, e vingué en aquell, e dix-li si tenia tal púlvora; respòs que sí, e foren lo preu per v sous: e lo specier hagué gran goig dels v sous e lo secretari de la púlvora, e aportà la púlvora devant lo rey al mercader. Lavors lo mercader pres lo saquet e assumà'l per la bocha e dix: "Aquesta és la púlvora”.

[I4] Entren-se'n ell e lo rey e lo secretari en la cambreta, e lo rey buffe al foch, lo secretari posa los creols, lo mercader mescla lo suffre e l'argent viu ab la púlvora de las dites dubles, e met-ho tot al foch. E finalment l'argent viu se convertex en àer, lo suffre en fum, e fou fet un bell carrell de fin aur. Lo rey mane al secretari que vage per los millors argenters de Londres, e tots dihen que és pus fin aur que lo noble de nau. Lavors lo rey fou molt alegres e féu gran festa al alquimiayre. [55] Dix lo mercader al rey: "Senyor, si havia gran quantitat de la púlvora, jo us faria gran quantitat d’aur, que seríeu lo major e pus rich senyor del món”. Tengueren consell que trametessen en Castella per la púlvora. Finalment, perquè la púlvora era ignota, e lo loch un era, determenaren que lo mercader passàs en Castella. Lo rey vestíl, ell e la sua companya, noblement, e donà-li XV mília nobles de nau, prometent que dins l'any seria tornat a Londres ab la púlvora. E lo mercader ab la companyia e ab la peccúnia anà-sse’n en tal punt que may no tornà. E lo rey tostemps sperava, e bé podia sperar. Aquest fóu bona alquímia!

[I6] Una nit, lo rey ab altres cavellers anava a la goyta, e foren prop de una taverna ab les portes no del tot tancades, e dins staven al foch de aquests vagabondos, e rahonaven-se alt; e lo rey scoltave'ls defora, e ells no.l vehien. [rz] Dix la un: “Qual és lo pus foll de la ciutat?” Dix l'altre: “Tal caveller, car son pare vivia virtuosament, e aquest viu viciosament”. Dix l'altre: "Ans és tal ciutedà, car lo pare era molt rich, e aquest ha-ho desbostat". Dix un: "Lo pus foll de la ciutat és lo rey". [18] En açò, lo rey donà gran colp a la porta, dient obrint la porta: "Al rey!". Lavors tots foren spaordits, en special aquell qui havia dit que lo rey era lo pus foll. [19] Dix lo rey: "Qual és aquell qui ha dit que lo rey és lo pus foll de la ciutat?" Respòs aquell qui ho havia dit: “Senyor, jo”. Dix lo rey: "E no has haguda vergonya ab tant pocha reverència parlar de ton senyor? Digues, ribalt, quina follia he jo feta?". Respòs: "Senyor, e no és gran follia donar XV mília nobles a home no conegut e qui nunqua lo veuràs?" Dix lo rey: "E si ve, serà follia?" Respòs: "Si ve, la follia serà mia de açò que he dit; si no ve, la follia romangue en tu de açò que has fet".

Després d'un breu exordi de transició a la nova matèria del frau fet en la cosa (§ I), el teòleg ha exposat la pena i els exemples dantescos de l'alquímia (\$ $\$ 2-4)$ a partir del Comentum de Pietro Alighieri. ${ }^{18}$ Val a dir que, en aquest cas, la punició que Pasqual pronostica als alquimistes ("en

18. In Inf. XXIX, 36-46: "Fingendo se postea invenire duos spiritus in quibus fuerat illorum qui laborant ad alchimiam falso fatiendam, qui die noctuque cum vasis fictilibus fabricant et buliunt, et quanto magis procedunt magis ardent procedere et minus acquirunt, ut fatiunt grattantes scabias, qui quanto plus scalpunt et gratant, magis gratare desiderant absque fine. Et ideo vide quare ut teghiis et scalpentes et grattantes scabiem eos fingat. Nominando magistrum Grifolinum de Aritio, combustum Senis per inquisitorem heretice pravitatis ad instantiam episcopi dicte 
lo present cercle la alquímia és punida segons l'acte, ço és en ardent foch bollints, ab demonis insuflants al foch") és invenció seva i no pas de Dante, encara que s’inspira en la descripció de l'obsessió alquímica que li forneix el Comentum. L'acció de bufar el foc del fornell és una de les més característiques en la sàtira de l'opus alchemicum, com tindrem ocasió de comprovar tot seguit. Així mateix, cap al final $\left(\S_{5}\right)$ Pasqual insisteix a denunciar l'obsessió morbosa dels practicants de l'ars alchemica, d'acord amb un tòpic freqüent en la censura moral de l'alquímia -i en algun dels textos que llegirem més avall-, vinculada a la concupiscència de riqueses. En canvi, la pruija de gratar-se, que és la pena prevista per la ficció dantesca, queda reduïda a un mer símil (§ 2$)$.

Però Joan Pasqual no s’aventura solament a proposar un nou turment, sinó també a identificar un nou damnat en aquest cercle: el fals alquimista del conte tradicional. Tota la resta del capítol consisteix en la narració d'aquest exemplum moral, que s'afegeix excepcionalment al repertori didàctic manllevat de la mitografia i la història. El relat de Pasqual ressegueix fil per randa una seqüència narrativa comuna a tots els testimonis de la versió extensa del conte de l'alquimista i el rei, amb algun canvi d'ordre ( $§$ II i, sobretot, I2), perfectament resolt, que no distorsiona gens el paral-lelisme. D’acord, això sí, amb una pràctica comuna i gairebé preceptiva -l'aplicació de l'exemplum al context i al públic del discurs-, Joan Pasqual recrea les circumstàncies del conte amb una considerable originalitat i les adapta a una realitat molt familiar als seus lectors, la minoria dirigent d'una potència mercantil com Barcelona. El protagonista de la seva versió és, doncs, un mercader arruïnat de Sevilla, principal port comercial de Castella, que aspira a refer-se estafant un conegut afeccionat a l'alquímia: el rei d'Anglaterra. Res no ens indica que es tracti d'Eduard III, però és indubtable que Pasqual -contemporani de Guglielmo Fabri i de Jean Saulnier (vid. supra I i nn. 7 i 9) -, vol atorgar versemblança històrica al seu exemplum al-ludint a una cort estretament associada amb l'alquímia en la memòria dels seus lectors, en part gràcies al corpus pseudolul-lià i, sobretot, a la llegenda de Llull alquimista. Una etapa important en el viatge del mercader, almenys com a indici de versemblança, és Portugal, amb unes intenses relacions comercials i marítimes amb Anglaterra. Entre els diversos elements que recreen l'ambient d'una gran ciutat com Londres -del gran hostal a la taverna, passant pels especiers, els argenters i la cort del rei-, el més característicament anglès és l'esment del noble de nau com a moneda d'or de la màxima puresa (§ I 4$)$. Cal tenir en compte que els elements integrants de la llegenda de Llull alquimista al segle XVI ja devien circular per Europa, i especialment en terres catalanes, en les primeres dècades del Quatre-cents (vid. supra I). Noteu, d'altra banda, la mateixa precisió numismàtica en el cas de les dobles -moneda d'or castellana i andalusina-que el mercader sevillà polvoritza en la preparació del truc $(\S 6)$. No ens sorprendrà pas gaire de trobar també doblas en els dos testimonis castellans del conte de l'alquimista i el rei, el Libro del conde Lucanor i el Zifar (vid. infra 3.I.I), mentre que en el Fèlix de Ramon Llull (vid. infra 3.I.5) ens podria semblar l'indici d'un model ibèric.

\section{En la perspectiva de la tradició}

Si la narració de Pasqual constitueix un document significatiu de la llegenda alquímica de la cort d’Anglaterra als segles XIV i XV, encara té un paper més rellevant en la transmissió del conte de l'alquimista i el rei, com es desprèn fâcilment d'una anàlisi comparativa de la seva versió amb els principals testimonis de la tradició: el Kitāb al-mukhtārfì kaixf al-asrār d'Al-Jawbarī, el Libro del

terre eo quod quidam nomine Arbor de Senis, filius dicti episcopi, deceptus fuit in pecunia ab ipso, promittendo ipsum facere scire volare, ut fecit ille Dedalus de quo dixi supra in capitulo XVII ${ }^{\circ}$. Item nominat alium alchimistam nomine Capochium, florentinum, combustum Senis" (Gómez 20I3b, 751). 
conde Lucanor de don Juan Manuel i l'anònim Libro del caballero Zifar per al conjunt de la versió extensa, a més del Fèlix o Llibre de meravelles de Ramon Llull per al motiu del fals alquimista, i del Novellino Borghini per al motiu del llibre dels folls. Per constatar-ho, en primer lloc compararem, unitat per unitat, cadascun dels episodis que integren la sequiència narrativa segons la versió de Pasqual, remarcant les constants de l'esquema tradicional, les variants dels testimonis i les seves possibles relacions. També comentarem tot seguit el context que emmarca cadascun dels testimonis i que hi dóna un sentit lúdic, didàctic, enciclopèdic i/o moral. Les conclusions d'aquesta anàlisi ens permetran d'esbossar un stemma narrationum que, finalment, ens servirà per a discutir, en un altre apartat, la difícil col-locació de The canon's yeoman's tale de Geoffrey Chaucer dins el quadre hipotètic de la tradició.

Citaré el conte d'Al-Jawbarī en una traducció catalana preparada per Alba Vinyes Lasso a partir de la recent edició crítica de Manuela Höglmeier (2006); els altres textos se citen tots a partir de les edicions indicades més amunt, en l’apartat I.

\section{I Anàlisi seqüencial}

\section{I.I L’estafador i la víctima $(\$ \S 6-9)$}

La narració de Pasqual presenta amb molta concisió els elements bàsics de la trama: I) la condició de l'estafador, un mercader arruïnat de Sevilla; 2) la condició de la víctima, un rei d'Anglaterra "molt afectat a l'alquímia"; 3) uns atributs d'opulència ("se vestí grans robes”, "prengué ab si tres escuders", "bé encavalcat, posà en un gran hostal”) que faran creïble la disfressa de gran alquimista (“car va bé e noblement vestit e encavalcat ab la sua companyia"), i 4) la preparació de l'ardit, consistent a llimar cent dobles d'or i introduir aquestes pólvores dins un saquet. Així que arriba a Londres, 5) l'estafador s'estableix luxosament en un "gran hostal” i es dóna a conèixer com a gran alquimista a l’hostaler ( $§$ ), el qual transmet al rei la bona notícia, avalada per tanta ostentació de luxe i de ciència (§ 8). Finalment, 6) el rei convoca l'alquimista a una entrevista, l'acull amb plaer i li prodiga regals i hospitalitat $(\S 9)$.

Les sis funcions que acabem de distingir es presenten anàlogament en la versió d'Al-Jawbarī. En aquest cas, l'estafador és un persa que arriba a Damasc; la seva víctima, el soldà d'Egipte i de Síria, Nūr-ad-Dīn Mạ̣mūd ibn Zangī (II47-74), tot i que no se’n destaca l’afecció a l'alquímia. La preparació de l'ardit consisteix a polvoritzar mil dinars d'or, per bé que les pólvores són amassades en forma de boletes amb altres ingredients combustibles; l'estranger fa ostentació pública de magnificència i es fa conèixer com a gran alquimista; el visir l'entrevista i s’afanya a parlar-ne al soldà, que també l'interroga i l'acull sumptuosament. Abans de donar-se a conèixer com a alquimista, el persa, disfressat de mendicant, ha venut les boletes a un especier o adroguer: Joan Pasqual també recull aquesta setena funció, però posposada (\$ I2; vid. infra 3.I.3). Un tret particular del relat d'Al-Jawbarī, però potser influent en la llegenda alquímica de Llull i del rei Eduard d'Anglaterra, és la motivació històrica i piadosa amb què es barreja la cobdícia dels estafats: l'alquimista adverteix al visir que només revelarà el secret de la transmutació alquímica a un rei que prometi d'invertir tot aquest or en la guerra santa contra els croats francs, i tant el visir com el soldà fan veure que no pensen en altra cosa i se sotmeten a aquesta condició:

Un cert foraster de Pèrsia arribà a Damasc, agafâ mil dinars egipcis i els llimà a consciència. Després agafâ mòlta de carbó i plantes medicinals, tot barrejat, i ho macerà tot junt. Llavors ho pastà amb cola de peix, n’afaiçonà boles en forma d'avellana i ho deixà ben assecar. [Venda a l'especier; vid. infra 
3.r.3] El foraster es partí d'ell i es vestí escrupolosament amb els vestits que solen dur els visirs. Es féu acompanyar d'un servent, s'acomodà en un allotjament digne d'un visir o d'un cadi i es passejava per la mesquita, fent coneixença de les personalitats més importants de la ciutat i creant-se una reputació [p. I9o], fent depesa d'una gran suma de diners. Afirmava que posseïa el coneixement de l'art, amb el qual era capaç d'obrar en un sol dia una gran quantitat d'or. Aquesta informació s'escampà per Damasc i les personalitats més importants aviat li demanaren que fes l'obra per a ells. -En aquest moment no necessito l'ajuda de ningú -els digué- per a produir en un sol dia tanta riquesa com tingui qui em vulgui per a obrar a casa seva. Quina necessitat tinc jo d'obrar per a ningú? No seria per a practicar l'art, perquè jo ja puc comprar-me deu jardins i deu cases, ara mateix; ni seria per a guanyar-hi prestigi, perquè no faria res que no domini ja, que això que jo obro no és una farsa ni conté cap engany. Aneu i busqueu algú que tingui fama en aquest ofici...! Jo l'únic que vull és fer l'obra per a un rei, però no fabricaré res si abans no em jura que només gastarà tot el que produeixi en les campanyes en nom de Déu, que Ell sigui lloat-. Després d'això la notícia va arribar a oïda del visir Musda'ani. El visir féu venir el foraster, el tractà amablement $i$ amb atencions per un temps fins que s'establí entre ells dos una amistat. Llavors encetaren una conversa: -Us juro, senyor meu, que la meva missió i el meu deure són fer l'obra només per a un rei, un cop s'hagi compromès a no cometre cap mena de frau i em prometi que no gastarà res del que jo fabricaré en cap altra cosa que no siguin les campanyes en nom de Déu, alabat i glorificat sia. Si això succeís, obraria només al servei d'aquesta causa-. Quan el visir sentí aquestes paraules, pensà un moment i digué: -Us juro que això seria una gran felicitat [p. I9I] per als musulmans i per al sultà, perquè tot aquest país és dels francs, fins a Banias, i cada dia una incursió arriba fins a casa seva; per tant, si fabriquessis tot això, conquistaríem aquella regió i això seria una benedicció majestuosa-. Després digué: -El sultà és d'aquest parer? -Sí. - Arregla una trobada entre ell i jo per a assegurar-te que farà el que he dit. -D'acord-. L'endemà el visir se n'anà per dur a terme la tasca, es reuní a soles amb el sultà $\mathrm{i}$ li féu saber tot allò:-Per Déu que ho he estat meditant, i no hi ha dubte que es tracta d'un ajut per a treure'ns del damunt i eradicar aquests maleïts. Porta l'home i tracta'l al millor possible -digué el sultà. Llavors agafâ una túnica i una mula ben ensellada i embridada. Va dur-ho al foraster, que es vestí la túnica i muntà la mula juntament amb ell. Tots dos pujaren i el visir presentà el foraster al sultà. Tots dos parlaren: -És veritat el que m’ha dit el visir? -digué el sultà. -Sí, senyor nostre, l'únic requisit depèn del sultà -respongué el foraster. -Doncs ho farem tal com dius -conclogué el sultà. (Al-Jawbarī, Kaixf al-asrār IX, 9, pp. I88-I9I)

Ramon Llull redueix el plantejament de l'exemplum a un esquema essencial i abstracte: un home ambiciós arrisca tot el que té en una gran estafa, presentant-se com a alquimista davant el rei d'un país llunyà, que l'acull amb alegria, hospitalitat i compliments. S'ometen les concrecions geogràfiques, l'ostentació de riquesa i els intermediaris, però es manté la descripció del procediment: tres bosses d'or polvoritzat -la lliçó molt dels manuscrits deu correspondre al participi de moldre, no pas a l'adverbi de quantitat-, amassat amb d'herbes cuites com una pasta o electuari:

En .i ${ }^{a}$. terra s'esdevench que un hom penssá com pogués ajustar molt gran tresor et vené tot quant havia. Et en una terra molt luny ell aná a un rey et dix que ell era alquimista. Aquell rey hac molt gran plaher de sa venguda et feu-li donar hostal e tot ço que mester havia. Aquell home hac mes molt aur [aur (auer amb la e ratllada) molt $m s$. $C$ ] en tres brusties, en les quals havia decocçió de erbes et era aquella decocçió en semblant de letovari. (Llull, Fèlix VI, 36[4].56-6I)

La versió de don Juan Manuel, menys esquemàtica però també sintètica i sense localització geogràfica, simplifica algunes funcions de l'estructura narrativa, com l'ostentació de riquesa, la divulgació de la notícia mitjançant intermediaris o la bona acollida del rei. En canvi, descriu molt bé, i en termes molt afins a la versió de Pasqual, tant la condició dels protagonistes - un "muy grand 
golfín", ambiciós i tip de misèria, i un rei insensat molt donat a l'alquímia- com el procediment de l'ardit -també llimadures de cent dobles d'or, amassades amb altres ingredients:

-Señor conde Lucanor - dixo Patronio-, un omne era muy grand golfín et avía muy grand sabor de enrequescer et de salir de aquella mala vida que passava. Et aquel omne sopo que un rey, que non era de muy buen recado, se trabajava de fazer alquimia. Et aquel golfín tomó cient doblas et limólas, et de aquellas limaduras fizo, con otras cosas que puso con ellas, cient pellas, et cada una de aquellas pellas pesava una dobla, et demás las otras cosas que él mezcló con las limaduras de las doblas. Et fuesse para una villa do era el rey et vistiósse de paños muy assessegados, [Venda a l'especier; vid. infra 3.I.3]. Et aquel golfín moró un tiempo en aquella villa en manera de omne muy assessegado et fue diziendo a unos et a otros, en manera de poridat, que sabía fazer alquimia. Et estas nuevas llegaron al rey, et envió por él et preguntól si sabía facer alquimia. (Juan Manuel, Lucanor XX, pp. 82-83)

Aquest "golfín tómo cient doblas et limólas" igual que, en la versió de Pasqual, "lo mercader prengué c dubles e féu-ne puls” (\$6), però també és notable, com veurem tot seguit, la coincidència amb el Libro del caballero Zifar: "E de las doblas que traya calçino veynte, e fizolas poluos...".

Cal tenir en compte que el Zifar ofereix un plantejament molt innovador, precisament perquè situa l'ambició del protagonista en un context social molt diferent. Ara es tracta del fill d'un barber ric que, educat a la cort d'un rei moro amb els fills de la noblesa, $i$ aspirant a la cavalleria, decideix d'emigrar a la cort d'un altre rei, on ningú no recordi la seva extracció tan humil. I és per ocultar la seva condició que improvisa un secreta dedicació a l'alquímia. Totes les funcions narratives s’adapten a la situació, i els intermediaris desapareixen -la funció del visir d’Al-Jawbarī, o de l'hostaler de Pasqual, la fa en aquest cas una "carta de ruego" o de recomanació. Els elements més fidels a la tradició són l'acollida del rei, amb plaer, hospitalitat i compliments, i la descripció de l'ardit, consistent en la calcinació i polvorització de vint dobles d'or:

Asy fue que vn rey moro auia vn alfajeme muy bueno e muy rico, e este alfajeme auia vn fijo que nunca quiso vsar del oficio de su padre, mas vso sienpre de caualleria, e era muy buen cauallero de armas. E quando murio su padre, dixole el rey que quisiese vsar del oficio de su padre, e quel feziese mucha merçed. E el dixole que bien sabie que nunca vsara de aquel oficio, e que sienpre vsara de caualleria, e que lo non sabia fazer asy commo conuenia; mas quel pedia por merçed que por non andar enuergoñado entre los caualleros quel conosçia, que sabian que era fijo de alfajeme, quel mandase dar su carta de ruego para otro rey su amigo, en que lo enbiase rogar quel feziese bien e merçed, e quel punaria en lo seruir quanto podiese. E el rey touo por bien de gela mandar dar, e mando a su chançeller que gela diese. E el cauallero tomo la carta e fuese para aquel rey amigo de su señor. [...] E el rey le pregunto que mester auia. E el cauallero quando lo ayo fue mucho espantado, ca entendio que en la carta dezia de commo era fijo de alfajeme. E estando pensando que repuesta le daria, preguntole el rey otra vegada que mester auia. E el cauallero le respondio: "Señor, pues atanto afincades e porque sodes amigo de mio señor, quiero vos dezir mi poridat. Sepades, señor, que el mi mester es fazer oro". "Chertas", dixo el rey, "fermoso mester es e cunple mucho a la caualleria, e plazeme mucho en la tu venida, e de Dios buena ventura al rey mio amigo que te aca enbio; e quiero que metas mano a la obra luego". "En el nonbre de Dios", dixo el cauallero, "quando tu quisieres". E el rey mando dar posada luego al cauallero, e mando pensar del luego muy bien. E el cauallero en esa noche non pudo dormir, pensando en commo podria escapar del fecho. E de las doblas que traya calçino veynte, e fizolas poluos... [Venda a l'especier; vid. infra 3.I.3] (Zifar, pp. 402-403)

Malgrat els elements innovadors, no hi ha dubte que l'Anònim del Zifar treballa sobre un esquema idèntic al dels altres testimonis del conte. També és evident que les versions del Zifari del Fèlix, les més allunyades d'Al-Jawbarī, no poden ésser la font dels altres dos testimonis, que en conserven totes les funcions narratives, encara que modificades amb criteris propis. Tampoc no sembla que 
l'autor del Zifar hagi partit del Lucanor, on s'ometen l'hospitalitat i els compliments que el rei prodiga a l'alquimista en els relats Al-Jawbarī, del Zifar i de Joan Pasqual. Malgrat la diferència premeditada de context geogràfic, cal remarcar que també hi ha notables coincidències particulars entre Joan Pasqual i Al-Jawbarī: el gran hostal, el servei i, sobretot, l'intermediari. Tot indica que els quatre testimonis romànics davallen independentment d'una font comuna, estretament emparentada amb el testimoni àrab.

\section{I.2 L'ingredient bàsic de l’opus alchemicum (§§ IO-II)}

Per a l'èxit de la presumpta experiència alquímica és imprescindible un ingredient desconegut, preparat en la seqüència anterior, l'adquisició del qual conforma una acció secundària perfectament planificada per a convèncer el rei no solament de l'autenticitat de l'experiència, sinó també de la raresa del producte, ocultant-ne alhora tota relació amb l'estafador. Ramon Llull prescindeix completament d'aquesta acció, i don Juan Manuel la simplifica, mentre que Joan Pasqual, com AlJawbarī i l'Anònim del Zifar, la desenvolupa en tres escenes (3.I.2-4), amb un lleuger canvi d'ordre.

En aquesta primera escena, l'alquimista fa creure al rei que l'ingredient bàsic de l'opus alchemicum és totalment desconegut i raríssim a Londres, mentre que al seu país és fâcil d'adquirir en abundància. Dins una atmosfera de secret, I) el rei prega d'assistir a una demostració de l'obra; 2) el mercader estafador enumera l'instrumental i els ingredients necessaris, incloent-hi les pólvores de nom desconegut; 3) el secretari del rei participa en l'experiment i en la provisió de materials; 4) la recerca de l'ingredient desconegut és infructuosa (dues vegades); 5) el mercader estafador se'n sorprèn, perquè assegura que al seu país és abundant, menyspreat i tan barat que se'n podrien carregar deu naus, i ho lamenta, perquè aquest ingredient és imprescindible.

Aquestes cinc funcions narratives també se succeeixen, amb més amplitud, en el relat d'AlJawbarī: I) l'estafador no vol manipular l'experiment, per evitar tota sospita d'engany, i el rei s'aplica a l'obra amb les seves pròpies mans; 2) la llista d'ingredients inclou un producte desconegut anomenat tatarboq-tabarmukk en les versions de René Khawam- de la remota província persa de Khorasan; 3) el majordom s'encarrega d'adquirir-ho tot, però 4) no troba tatarboq ni entre els especiers de Damasc ni a l'hospital dels pobres; 5) l'estafador se'n sorprèn, afirma que és imprescindible i proposa una solució: ell mateix participarà en un escorcoll sistemàtic, demanant que totes les botigues dels adroguers siguin segellades per a garantir l'autenticitat del procés. Més endavant -és un passatge que Pasqual probablement anticipa (§ II) - serà evident que caldrà portarne de Khorasan, on seria fâcil carregar-ne mil camells:

-Nostre senyor el sultà ha decretat que tots els qui practiquen aquesta art són mentiders i estafadors i causen la destrucció de tot. Per tant, només hi ha una cosa [p. 192] que dic al nostre senyor el sultà: la meva condició és que no tocaré res amb la meves mans, sinó que estaré lluny d’ell i li diré “feu això o allò", i nostre senyor ho farà. Un cop decidida aquesta regla d'actuació... -En nom de Déu -el tallà el sultà-, procedeix, amb la benedicció de Déu-. El persa agafâ un full i els escrigué tot el que havia de menester: -De tal ingredient, tant, i de tal altre... -i cità diversos ingredients-....I de tatarboq de Khorasan, cent unces -digué. Llavors lliurà el full al majordom i li digué: -Porteu-me aquests ingredients-. Els portà tots; bé, fou capaç de portar-los tots, excepte el tatarboq: els digué que no en trobava ni a l'Hospital dels pobres ni als especiers. -Com pot ser que a Damasc no hi hagi tatarboq! -respongué l'estranger. -No tenim res per a poder prescindir d'aquest ingredient? -digué el sultà. -No - digué el foraster-, Damasc no n'és buida, de tatarboq. Cal que nostre senyor demani al notari que aquesta nit tanquin les botigues dels adroguers. Llavors demà jo, amb ell $\mathrm{i}$ dos testimonis dignes de fe, obrirem botiga rere botiga, en buscarem i, sens dubte, en trobarem. -D'acord, que es faci tal com dieu -féu el sultà. El notari era conegut com “el cabdill”. El van fer comparèixer i s’hi va presentar. [...] El foraster respongué: -Si ordenes portar-ne, en trobaràs a 
Khorasan. És un mineral que es troba en certa muntanya, en una caverna. El camí és tal i tal... Si algú volgués endur-se'n mil càrregues de camell, ho podria fer tan fâcilment com jo, que m'hi ficat dins i n'he agafat molt. Tinc per a tal feina tres picapedrers-. (Al-Jawbarī, Kaixf al-asrär IX, 9, pp. I9I-92 i I94)

El Zifar ressegueix fil per randa aquest esquema, amb algunes peculiaritats: I) l'autor amplifica l'avidesa impacient del rei moro i al-ludeix breument als beneficis de l'or per a la guerra -vet aquí un altre possible ressò del motiu de la croada en la tradició europea, a part de la llegenda pseudolul-liana-; 2) la llista d'ingredients es redueix a unes pólvores d'alexandrique; 3) la recerca s'encomana al majordom del rei i a un altre home de confiança; 4) resulta infructuosa dues vegades -com en Pasqual-, perquè cap especier no n’ha sentit a parlar mai abans; 5 ) el cavaller estafador se'n sorprèn, perquè al seu país seria fâcil carregar-ne dues-centes atzembles - "çient" diu més avall (p. 405)-, i també participa personalment en l'escorcoll de les especieries:

...e el cauallero fuese a casa del rey, que auia ya enbiado por el. E el rey quando lo vio, mando a todos que dexasen la casa, e finco solo con aquel cauallero, e dixole asy: "Cauallero, en grant codiçia me has puesto, que non puedo folgar fasta que meta mano en esta obra". "Certas, señor", dixo el cauallero, "derecho fazes; ca quando rico fueres, todo lo que quisieres abredes, e reçelarvos han todos vuestros vezinos asy commo fazen a mi señor el rey, por el grant auer que tiene, quel yo fis desta guisa". "Pues que es lo que auemos mester", dixo el rey, "para esto fazer?" "Señor", dixo el cauallero, "manda algunos tus omes de poridat que vayan buscar por los mercaderos e por los espeçieros poluos de alexandrique, e conpralos todos quantos fallares; ca por lo que costare vna dobla fare dos, e sy para todo el año ouieremos abondo de los poluos, yo te fare con grant tesoro, que non lo abras do poner". "Par Dios, cauallero", dixo el rey, "buena fue la tu venida para mi, sy esto tu me fazes". E enbio luego a su mayordomo e a otro ome de su poridat con el que fuese buscar estos poluos. E andudieron por toda la villa a buscar estos poluos e nunca fallaron ome que les dixiese que los conosçiese nin sabian que eran, e tornaron se para el rey e dixieronle que non fallauan recabdo ninguno destos poluos; ca dezian mercaderos e los espeçieros que nunca los vieran nin oyeran fablar dellos sy non agora. "Commo non!", dixo el cauallero. "Çertas tantos traen a la tierra de mio señor el rey, que dozientas azeymilas podria cargar dellos; mas creo que porque los non conosçedes non los sabedes demandar. Yre conbusco alla, e por auentura fallarlos hemos". "Bien dize el cauallero", dixo el rey. "Ydvos luego para alla". E ellos se fueron por todas las tiendas de los espeçieros preguntando por estos poluos, e non fallaron recabdo ninguno. [...] "Señor", dixo el cauallero, "manda enbiar a la tierra de mio señor el rey, que y podran auer syquiera çient azeymilas cargadas". (Zifar, pp. 403-404 i 405)

La versió del Lucanor discrepa molt dels altres testimonis, perquè omet totes les dificultats per a obtenir l'ingredient desconegut i les reaccions d'estranyesa de l'estafador. Com veurem, el golfín es limita a incloure "una pella de tabardie" en la recepta de la fórmula, sense subratllar-ne la raresa ni advertint que sigui imprescindible, cosa que el rei descobreix al final (vid. infra 3.I.6). Don Juan Manuel tampoc no desenvolupa el paper dels servidors que s'ocupen implícitament de la provisió d'ingredients. El golfin es guanya la confiança del rei fingint desinterès i prevenint-lo, precisament, contra el perill d'una estafa, tot i que, de fet, és d'ell mateix que parteix la iniciativa de la demostració:

Et el golfín, commo quier quel fizo muestra que se quería encobrir et que lo non sabía, al cabo diol a entender que lo sabía, pero dixo al rey quel consejava que deste fecho non fiasse de omne del mundo nin aventurasse mucho de su aver, pero si quisiesse, que provaría antél un poco et quel amostraría lo que ende sabía. Esto le gradesció el rey mucho et paresciól que segund estas palabras que non podía aver ý ningún engaño. Estonce fizo traer las cosas que quiso, et eran cosas que se podían fallar, et 
entre las otras mandó traer una pella de tabardíe. Et todas las cosas que mandó traer non costaban más de dos o tres dineros. (Juan Manuel, Lucanor XX, p. 83)

És evident que el Lucanor no és pas la font de les versions del Zifar i de Pasqual, estructuralment anàlogues al testimoni àrab, respecte del qual ofereixen discrepàncies comunes -la repetició infructuosa de la recerca-, com també coincidències per separat. El "nom innot" del fals ingredient de Joan Pasqual rep els noms volgudament incomprensibles de tatarboq o tabarmukk en els manuscrits d'Al-Jawbarī i de tabardíe en don Juan Manuel, ${ }^{19} \mathrm{i}$ cal suposar que un terme semblant, substituït per alexandrique en el Zifar -potser una adaptació de l’àrab al-iksīr, 'elixir, pólvores, pedra filosofal’-, devia figurar en un antecedent hipotètic dels testimonis romànics.

\section{I.3 L’especier (§ I2)}

Joan Pasqual ha posposat una escena -el mercader proporciona l'ingredient desconegut a un especier vell i pobre-que en els testimonis paral-lels es narra immediatament després de descriure la polvorització de les monedes d'or (3.I.I). Aquest canvi d'ordre no exigeix modificacions substancials, però permet que el mercader pugui advertir a l'especier que el secretari reial cerca ansiosament aquest producte i que, sens dubte, no trigarà a comparèixer per comprar-ne. En la versió de Pasqual, I) l'especier és vell i pobre; 2) sense explicar-li’n les propietats, 3) el mercader li regala la substància per compassió fingida, 4) afirmant que al secretari pot demanar-li’n cinc sous, és a dir, cinc vegades el seu valor real, que no és gaire, només un sou; llavors l'especier 5) la pren molt content, perquè tindrà algun guany, i la desa.

Aquí l'escena anàloga d'Al-Jawbarī ens permet de constatar diferències molt notables: I) l'especier no és vell ni pobre; 2 ) l'estafador atribueix al producte nombroses propietats medicinals, no pas transmutatòries; 3 ) després de regatejar, el ven per cinc dirhams o monedes d'argent, tot i afirmar que 4) val el seu pes en or -cosa que el lector sap que és literalment certa-; 5) l'especier pren i desa les pólvores, i el narrador pondera el risc que l'estafador és capaç d'assumir. Però la diferència més notable és que l'estafador es presenta davant l'especier amb la disfressa d'un pelegrí amb aparença de captaire o d'asceta mendicant, com un remeier pobre, completament oposada a l'opulència que ostenta com a alquimista. Aquesta disfressa és necessària perquè l'especier no el reconegui quan comparegui davant seu, per comprar les pólvores, amb un vestit més luxós. Serà en aquell moment que apareixerà el motiu de la compassió envers l'especier (vid. infra 3.I.4), que manca, evidentment, en aquesta escena. Aquí apareix també un "sarronet" que recorda el "saquet de aluda" (§ 6) que l’especier de Pasqual “stuge” (§ ı2):

Es vestí amb una roba pobra, prengué l'aparença dels mendicants, posà [p. 189] aquelles boletes en un sarronet i s'arribà a un adroguer. -Em compraríeu això? -li digué. -I què és, això? -respongué l'altre. -És tatarboq de Khorasan -respongué. El seu significat es burla de tu, lector. -I això per a què em serà útil? -preguntà el comerciant. -És útil com a contraverí i forma part de la composició de molts remeis per a prevenir malalties -respongué l'altre-. És d'una utilitat formidable i, si no m'hagués sorprès aquí en temps de pelegrinatge, fet que m'impedeix dur-lo amb mi, no el vendria pas, que val el seu pes en or, per a qui el coneix. -A quin preu el vens? -digué l'adroguer. -A deu dirhams -respongué el persa. -Te’n dono tres -digué l'altre. Ell s'hi negà. Finalment l'hi comprà per cinc dirhams. Llavors el desà en un pot de terrissa i l'estranger agafa els dirhams i se n’anà.

I9. Per a hipòtesis sobre el joc de paraules del neologisme àrab -el mateix Al-Jawbarī diu que és un nom que desafia o burla (tan-z-bik) la comprensió del lector-, vegeu Höglmeier 2006, 435, i Khawam I979, I, 2I5 n. I ('tela grossera'). Moltes de les hipòtesis relatives al terme tabardie (resumides per Serrano Reyes i996, 34I-5O, esp. 344-48; Fradejas Lebrero 200I, I38) no tenen en compte el precedent d'Al-Jawbarī. 
Observa aquest home, lector, que tingué el valor de vendre mil monedes d'or per cinc dirhams. Com se sol dir, "qui arrisca quelcom de valuós, obté quelcom de valuós". (Al-Jawbarī, Kaixf al-asrār IX, 9, pp. I88-89)

La versió del Zifar no inclou el motiu de la disfressa, perquè, tot i que el cavaller participarà en la recerca de l'alexandrique, comptarà amb la complicitat de l'especier. Malgrat aquesta innovació, presenta moltes afinitats amb les narracions d'Al-Jawbarī i, encara més, de Pasqual, com ara el pretès altruisme del fals alquimista envers un especier ravaler, a qui tampoc no explica les possibles aplicacions transmutatòries del producte. El cavaller es limita a suggerir-li un tripijoc per a poder vendre'l més car -s’insinua que hi haurà algú molt interessat a obtenir-ne a qualsevol preu-i a acordar-hi tant un preu de venda, deu dobles, com un repartiment de beneficis:

...e fue a vn espeçiero que estaua en cabo de la villa e dixole asy: "Amigo, quiero te fazer ganar, e ganare contigo". "Plazeme", dixo el espeçiero. "Pues tomad estos poluos", dixo el cauallero, "e sy alguno te veniere a demandar sy tienes poluos de alexandrique, dy que poco tienpo ha que ouiste tres quintales dellos, mas mercadores venieron e te lo conpraron todo e lo leuaron, e que non sabes sy te finca algunt poco. E quando los catares, di que non te fincaron sy no estos pocos, e non lo des menos de dies doblas; e las çinco doblas daras a mi, e las otras çinco fincaran contigo". E el espeçiero tomo los poluos e guardolos muy bien. (Zifar, p. 403)

En tot cas, interessa observar que tant en el Kaixfal-asrär com en el Zifar el fingit alquimista intervindrà en l'adquisició de l'ingredient: un problema narratiu que resolen de maneres diferents, i que Pasqual eludirà mantenint-lo al marge de la recerca (vid. infra 3.I.4).

L'episodi anàleg del Lucanor no presenta aquí indicis particulars d'afinitat ni amb el Kaixfalasrär ni amb els altres testimonis romànics. Al fals alquimista del Lucanor no li cal cap disfressa addicional, perquè en aquesta versió s'ometen totes les dificultats d'obtenció del tabardíe. També s'ometen, però, tots els motius comuns a Joan Pasqual i al Zifar, perquè l'única funció de l'episodi és posar en circulació el producte i garantir que el rei el pugui trobar. El golfín, doncs, simplement ven el producte a un especier, per dues o tres dobles, assegurant-li que posseeix, això sí, propietats imprescindibles per a l'alquímia, entre moltes d'altres:

...et levó aquellas pellas et vendiólas a un especiero. Et el especiero preguntó que para qué eran aquellas pellas, et el golfín díxol que para muchas cosas, et señaladamente que sin aquella cosa que se non podía fazer el alquimia, et vendiól todas las cient pellas por cuantía de dos o tres doblas. Et el especiero preguntól cómmo avían nombre aquellas pellas, et el golfín díxol que avían nonbre tabardíe. (Juan Manuel, Lucanor XX, p. 82)

\section{I.4 La troballa de l’ingredient ( $\$$ I3)}

L'acció secundària del conte culmina i es resol amb la troballa de l'ingredient imprescindible per a l'obra alquímica. L'escena s'omet, per descomptat, en la versió del Lucanor, que ha prescindit de les dificultats d'obtenció. En la versió de Joan Pasqual, I) el mercader guanya credibilitat fingint desinterès i amenaçant d'anar-se'n; 2) interrogat pel rei, el secretari reconeix que la recerca no ha estat exhaustiva, sinó selectiva, i el mercader li aconsella de cercar entre els especiers vells i pobres, però 3) no intervé personalment en la recerca; 4) el secretari adquireix les pólvores pel preu que el mercader sevillà havia indicat a l'especier, i 5 ) el mercader, finalment, les identifica.

El fals alquimista d'Al-Jawbarī sí que participa en la recerca de l’ingredient desconegut, però ho fa sense possibilitat de manipular-lo, acompanyat d'un funcionari i de deu testimonis per a garantir 
l'absència de frau i evitar qualsevol ombra de sospita. Aquesta diferència n'explica d'altres, encara que les funcions narratives són anàlogues. En arribar a l'especieria on ha col-locat el producte amb la disfressa de remeier pobre, el fals alquimista l'identifica i el recipient és segellat. Amb una compassió fingida que retrobem en el Zifar i, sobretot, en Pasqual (§ I2), l'alquimista interroga l'especier perquè n'expliqui l'origen abans de pagar-li'n deu monedes de plata, i finalment la comitiva compareix davant el rei, que frisa per començar:

L'endemà el foraster acudí a fer la feina. S'endugué amb ell els testimonis i baixaren amb el cabdill. Llavors van posar-se a obrir botiga rere botiga fins que acabaren a la botiga en què el foraster havia venut [p. 193] el tatarboq. Els testimonis, el notari i el foraster van seure. El propietari de la botiga va baixar i va anar deixant als seus peus recipient rere recipient, fins a arribar al pot de terrissa que contenia la mescla. Quan el foraster la veié, la seva expressió es tornà exultant i digué amb alegria: -Això és el que farà feliç el sultà-. I digué al cabdill i als testimonis: -Segelleu-lo amb el vostres segells i envieu-lo cap al castell-. Així ho feren. Després tingué compassió de l'apotecari i li preguntà: -D'on has tret aquest producte? -El vaig comprar a un home per cinc dirhams-. Deslligà el seu mocador i digué: -Aquests deu dirhams són el que te’n puc donar. No descuidis la teva feina-. Se n'anaren, pujaren tots cap al castell i informaren el sultà. El foraster digué: -Aquesta és la primera alegria del sultà; això ens ajudarà a produir molt-. (Al-Jawbarī, Kaixf al-asrār IX, 9, pp. I92-93)

Malgrat alguna innovació particular, derivada de la complicitat entre el cavaller i l'especier, la narració del Zifar també presenta una remarcable analogia amb els altres dos testimonis de l'escena: com en l'exemplum de Pasqual, la recerca s'estén als especiers del raval després que el majordom, interrogat, aclareix que els havien deixat de banda; com en Al-Jawbarī, el cavaller intervé personalment en la recerca, acompanyat del majordom. Quant a l'origen del producte, l'especier actua d'acord amb el guió pactat amb el cavaller per a justificar-ne l'escassetat, i rep el preu de deu dobles. Les pólvores són custodiades primer pel majordom i després pel rei, sense passar per les mans del cavaller:

E el cauallero demando al mayordomo del rey sy auia otras tiendas de espeçieros y açerca, que fuesen alla, que no podia ser que los non fallasen. "Chertas", dixo el mayordomo, "non ay otras tiendas en toda la villa, saluo ende tres que estan en el arraual”. E fueron para alla, e en las primeras non fallaron recabdo ninguno; mas vno que estaua mas en cabo que todas, dixo que poco tienpo auia que leuaron mercaderos del tres quintales de tales poluos commo ellos dezian. E preguntaronle sy fincara alguna cosa ende, e el dixo que non sabia, e fizo commo que escrudiñaua sus arcas e sus sacos, e mostroles aquellos pocos de poluos quel auia dado el cauallero. E demandaronle que por quanto gelos daria, e el dixo que non menos de dies doblas. E el cauallero dixo que gelas diesen por ello, syquier por fazer la proeua, e dieronle dies doblas, e tomo los poluos el mayordomo e leuolos para el rey. E dixieronle commo non podieran auer mas de aquellos poluos, commoquier quel espeçiero les dixiera que poco tienpo auia que vendiera tres quintales dellos. E el cauallero dixo al rey: "Señor, guarda tu estos poluos..." (Zifar, pp. 404-405)

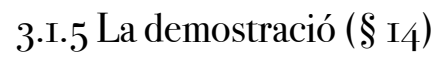

Per a obrar, per fi, la farsa de la crisopea, Joan Pasqual I) tanca el rei, el secretari i el mercader dins una cambra secreta, 2) assigna una acció concreta a cadascun i, sobretot, 3) ens revela el funcionament del truc, descrivint amb precisió els fenòmens físics -l'evaporació del mercuri, la combustió del sofre, la fusió de l'or- que produeixen l'efecte aparent de la transmutació. Finalment, 5) la puresa de l'or alquímic és aprovada pels millors argenters de Londres, i 6) el rei exulta de goig. 
A més d'acreditar la versemblança d'un exemplum emmarcat en l'Anglaterra contemporània, la referència numismàtica a la puresa del noble de nau podria evocar alguna forma de la llegenda del nobile Raimundi (vid. supra I i n. II).

A diferència del mercader de Pasqual, l'estafador d'Al-Jawbarī es manté al marge de l'operació mentre el rei executa les seves instruccions amb l'assistència d'un criat. L'experiment es repeteix fins a l'exhauriment de l'ingredient desconegut. El context, el procediment i l'estupefacció del rei són anàlegs, encara que el truc no es descriu amb tanta precisió:

El senyor aquella nit començà la feina, que la fortuna estigui en la mà de Déu. Tan bon punt arribà el vespre, van demanar tot l'instrumental que havien de menester. Llavors el sultà i el seu ajudant s'assegueren a la banqueta. El persa ja s'havia apartat d'ells en un racó. Aleshores digué: -Que nostre senyor pesi tal ingredient $i$ tal altre-. I començaren a ser pesats tots els ingredients. - I de tatarboq, cent unces -digué. Ho féu, i col-locà [p. I94] tots els ingredients al gresol. Finalment li digué: -Bufeu!-. I continuà així fins que es cremà tot i esdevingué or. Digué: -Aboquem-ho, amb la benedicció de Déu i la seva ajuda-. I succeí: la mescla s'havia convertit en un lingot d'or egipci del preu més elevat, perquè no n'hi ha de més pur i elevat. Quan el sultà s'ho mirà, quedà perplex i astorat. Aquella nit el persa li’n proporcionà una quantitat equivalent a tres mil [deu mil en el ms. d'Istanbul, quelque mille Khawam 1979-80, 1, 223] dinars. (Al-Jawbarī, Kaixfal-asrär IX, 9, pp. I9394)

Don Juan Manuel descriu l'experiment d'una manera encara més sintètica, sense enumerar tampoc els ingredients que intervenen en la fusió. El tret més singular d'aquesta versió és que el rei, de primer, només assisteix a la demostració del golfin, mentre que després, ja en possessió de la recepta, és capaç de repetir tot sol l'experiment una vegada i una altra, sense l'ajut de l'estafador, fins a exhaurir l'ingredient bàsic:

Desque las traxieron et las fundieron antel rey, salió peso de una dobla de oro fino. Et desque el rey vio que de cosa que costaba dos o tres dineros salía una dobla, fue muy alegre et tóvose por el más bienandante del mundo et dixo al golfín que esto fazía, que cuydava el rey que era muy buen omne, que fiziesse más. Et el golfín respondiól commo si non sopiesse más daquello:-Señor, cuanto yo desto sabía, todo vos lo he mostrado, et daquí adelante vós lo faredes tan bien commo yo; pero conviene que sepades una cosa: que cualquier destas cosas que mengüe non se podría fazer este oro-. Et desque esto ovo dicho, espedióse del rey et fuesse para su casa. El rey probó sin aquel maestro de fazer el oro, et dobló la recepta et salió peso de dos doblas de oro. Otra vez dobló la recepta, et salió peso de cuatro doblas; et assí commo fue cresciendo la recepta, assí salió pesso de doblas. Desque el rey vio que él podía fazer cuanto oro quisiese, mandó traer tanto daquellas cosas para que pudiese fazer mill doblas. (Juan Manuel, Lucanor XX, p. 83)

El cavaller del Zifar també es limita a donar instruccions, com el fals alquimista del Kaixf al-asrār, però el rei estafat no participa en l'experiència tan activament com en les altres versions. D'altra banda, l'Anònim descriu un fenomen físic de calcinació del plom amb la mateixa pruijja de precisió que Joan Pasqual, tot i que el truc és diferent. Les al-lusions a la puresa de l'or i a l'exultació del rei són pràcticament inevitables i comunes a la tradició:

“...e manda tomar plomo, pesso de veynte doblas, e fas traer carbon para lo fundir, e faga el tu mayordomo en commo le yo dire, e sey çierto que me fallara verdadero en lo que te dixe". "Quieralo Dios", dixo el rey, "que asy sea!" Otro dia en la mañaña vino el cauallero e mando que posiesen en vn cresuelo los poluos e el plomo, e que lo fundiesen, e mandoles lançar otros poluos desuso de la calçina, de los huesos, que desgasto el plomo e lo torno en fumo, e fincaron los poluos de las veynte doblas todo fundido. E quando lo sacaron, fallaron pesso de veynte doblas del mas fino oro e mas 
puro que podia ser. E el rey quando lo vio, fue muy ledo e touo quel auia fecho Dios mucha merçed con la venida de aquel cauallero... (Zifar, p. 405)

El rei també es limita a assistir a la demostració, sense participar-hi mai, en el testimoni romànic més antic, el Fèlix de Ramon Llull. La versió de Llull presenta, a més a més, dos trets molt característics: l'experiment és executat per l'alquimista amb les seves pròpies mans, i consisteix en una obra, no pas de transmutació de metalls, sinó de multiplicació de l'or, repetida tres vegades:

Denant lo rey mes aquell home una d'aquelles brusties en la caldera on fonia gran re de dobles que.l rey li havia donades, per tal que les muntiplicás. L’aur qui era en la brustria pesava mil dobles; e.l [ed. el] rei n’avia meses dos milia en la caulera et a la fi pesá la massa del aur tria milia dobles. Per tres veguades feu açó l'ome e.l rey cuydá·s que fos alquimista segons veritat. (Llull, Fèlix VI, 36[4].6I-66)

Lògicament, l'escena de la demostració de l'opus alchemicum sempre inclou, d'una banda, una descripció més o menys precisa de l'experiment i, de l'altra, la reacció del rei, que, davant l'evidència que l'experiment funciona, cau irremissiblement al parany. Don Juan Manuel desenvolupa lliurement el mateix plantejament que Al-Jawbarĩ: no detallen els ingredients ni descriuen en concret a cap fenomen físic, i el rei és capaç de reproduir l'experiment, sense la intervenció directa de l'estafador, fins que s'acaba l'ingredient bàsic. Cal suposar que aquest és l'esquema arquetípic de la tradició europea. Ramon Llull o el seu model se n’aparta per oferir-ne una versió més sintètica, mentre que l'Anònim del Zifar i Joan Pasqual coincideixen a revelar el truc de l'estafador detallant els ingredients i els fenòmens naturals que intervenen en l'experiment, amb la separació de les substàncies volàtils i la fusió de l'or.

$$
\text { 3.I.6 La fugida amb el botí ( } \text { I5) } \text { ) }
$$

La fugida del fals alquimista amb els diners de la víctima representa la conclusió del primer motiu tradicional (K.III.4). En la versió de Joan Pasqual, el mercader sevillà és tramès a Castella amb gran pompa i una gran suma de diners en moneda anglesa per a l'adquisició de l'ingredient desconegut, i ja no tornarà. Aquesta fugida implica almenys cinc motius principals: I) es presenta la necessitat d'aconseguir més quantitat de l'ingredient desconegut, i abans el mercader ja ha dit que a la seva terra se’n troba en gran quantitat i a baix preu (3.I.2); 2) s'organitza una expedició al seu país i es considera convenient que ell mateix l'encapçali; 3 ) el rei el proveeix molt ricament, i el mercader parteix; 4) el rei l'espera debades; 5) ironia final del narrador: una estafa tan exitosa és, sens dubte, la millor alquímia que es pugui fer.

La seqüència és perfectament paral-lela en la narració d'Al-Jawbarī, tot i que els tres primers motius s'hi presenten amb més amplitud i complexitat: el soldà intenta vanament de trobar l’ingredient bàsic a Damasc, abans que el persa l'informi que al seu país és un producte abundant; el foraster fingeix de resistir-se a encapçalar l'expedició i suggereix que ho faci algú altre; es descriuen detalladament els preparatius de l'expedició. La ironia final és pràcticament la mateixa que recollirà Pasqual (“Aquest fóu [sic, enteneu 'féu'] bona alquímia!") :

No s'aturaren i treballaren fins que s'acabà el tatarboq. En demanà més, però no en trobà. Aleshores el sultà li digué: -Com podem aconseguir tatarboq?-. El persa respongué: -Si ordenes portar-ne, en trobaràs a Khorasan. És un mineral que es troba en certa muntanya, en una caverna. El camí és tal i tal... Si algú volgués endur-se'n mil càrregues de camell, ho podria fer tan fâcilment com jo, que m’hi he ficat dins i n’he agafat molt. Tinc per a tal feina tres picapedrers-. Quan el sultà ho sentí, digué: -No trobo que ningú pugui fer-ho millor que tu. Si no ets capaç d'arribar a la cova, torna amb la quantitat que en tinguis, i si arribes a la cova, carrega'n tant com puguis. Escriuré una lletra 
per al Gran Sultà, per tal que no et sigui impedit d'agafar-ne la quantitat que vulguis-. Quan el foraster oí tot allò, digué: -Si el sultà opina que s’hi pot enviar algú altre, que ho faci. A mi m’agrada Damasc i servir nostre senyor el sultà. -Ets indispensable per a fer aquesta tasca -digué el sultà. El sultà no cessà d'insistir fins que el foraster accedí a fer el viatge i, tan bon punt fou així, es posà a enllestir els preparatius a consciència amb seixanta càrregues de begudes de la província de Tanis $\mathrm{i}$ de Damiata i d'Alexandria i les mateixes càrregues de sucre rosat, de camàlics i de camells. Llavors li donà una tenda, un fornell, una comuna, [p. 195] un matalàs i els diners per a les despeses del camí fins a Bagdad i quelcom per vendre durant el viatge. S'enduia amb ell cartes cap a la resta de regions perquè el servissin i l'allotgessin. El sultà i les autoritats del regne sortiren a acomiadar-lo i se'n va anar. I vet aquí que va arribar a la pedra venerable i la transformà en el major elixir! (Al-Jawbarī, Kaixf al-asrär IX, 9, pp. 194-95)

Don Juan Manuel també ofereix una seqüència anàloga, però tendeix a resumir, i ha d'introduir alguns canvis per coherència amb innovacions anteriors. D'una banda, redueix els tres primers motius a la mínima expressió, però conserva un lleu ressò de les protestes amb què l'estafador fingeix de refusar a encapçalar el viatge ("commo quier que esto podría fazer otri tan bien o mejor que él”) que hem remarcat en la versió d'Al-Jawbarī; cal suposar, doncs, que aquest detall figurava en l'antecedent dels testimonis romànics. D’altra banda, recordeu que és precisament al començament d'aquesta escena que el rei del Lucanor pren consciència que el tabardie és un ingredient imprescindible i rar, cosa que abans no s'havia especificat (vid. supra 3.I.2). Al final el rei espera debades, però en aquesta versió és el mateix golfín que el desenganya, de la manera més original:

Et fallaron todas las otras cosas, mas non fallaron el tabardíe. Desque el rey vio que, pues menguava el tabardíe, que se non podía fazer el oro, envió por aquel que gelo mostrara fazer et díxol que non podía fazer el oro commo solía. Et él preguntól si tenía todas las cosas que él le diera por escripto. Et el rey díxol que sí, mas quel menguava el tabardíe. Estonce le dixo el golfín que por cualquier cosa que menguasse que non se podía fazer el oro, et que assí lo avía él dicho el primero día. Estonce preguntó el rey si sabía él dó avía este tabardíe, et el golfín le dixo que sí. Entonce le mandó el rey que, pues él sabía dó era, que fuesse él por ello et troxiesse tanto, por que pudiesse fazer tanto cuanto oro quisiesse. El golfín le dixo que commo quier que esto podría fazer otri tan bien o mejor que él, si el rey lo fallasse por su servicio, que yría por ello, que en su tierra fallaría ende asaz. Estonce contó el rey lo que podría costar la conpra et la despensa, et montó muy grand aver. Et desque el golfín lo tovo en su poder, fuesse su carrera et nunca tornó al rey. Et assí fincó el rey engañado por su mal recabdo. Et desque vio que tardava más de cuanto devía, envió el rey a su casa por saber si sabían dél algunas nuevas. Et non fallaron en su casa cosa del mundo sinon un arca cerrada, et desque la abrieron, fallaron ý un escripto que dizía assí: "Bien creed que non ha en el mundo tabardíe, mas sabet que vos he engañado. Et cuando yo vos dizía que vos faría rico, deviérades me dezir que lo feziesse primero a mí et que me creeríedes”. (Juan Manuel, Lucanor XX, pp. 83-84)

Val a dir que aquesta innovació irònica de don Juan Manuel genera dues incongruències que encara fan més palpable el motlle tradicional del seu conte. D’una banda, el golfín desenganya el rei mitjançant una nota, però tot seguit, d'acord amb l'esquema del segon motiu tradicional, el rei continua enganyat i no descarta la possibilitat que l'alquimista torni (3.I.7). De l'altra, el golfín denuncia la credulitat del rei amb un tòpic antialquímic ("deviérades me dezir que lo feziesse primero a mí et que me creeríedes”) també reblat al final del capítol per uns versos del comte Lucanor (vid. infra 3.2); aquest tòpic, però, aquí no hi fa gaire al cas, atès que a l'inici del conte (3.I.I) el golfín ha guanyat credibilitat oferint precisament mostres d'opulència ("et vistiósse de paños muy assessegados", "Et aquel golfín moró un tiempo en aquella villa en manera de omne muy assessegado"). 
La versió del Zifar recull molt esquemàticament tots els motius de la seqüència d'Al-Jawbarī, al-ludint també a la resistència que el cavaller només ha insinuat ("non quiero que otro vaya sy non tu”) i concloent amb una ironia molt implícita i diversa:

...e demandole commo podia auer mas de aquellos poluos para fazer mas obra. "Señor", dixo el cauallero, "manda enbiar a la tierra de mio señor el rey, que y podran auer syquiera çient azeymilas cargadas". "Chertas", dixo el rey, "non quiero que otro vaya sy non tu, que pues el rey mio amigo fiaua de ti, yo quiero fiar de ti otrosy”. E mandole dar dies camellos cargados de plata, de que conprase aquellos poluos. E el cauallero tomo su auer e fuese, con entençion de non tornar mas nin de se poner en lugar do el rey le podiese enpesçer; ca non era cosa aquello quel rey queria que feziese, en quel podiese dar recabdo en ninguna manera. (Zifar, p. 405)

En canvi, Ramon Llull conclou aquí, sense ironia i amb una dràstica simplificació de l'estafa, coherent amb l'omissió de tota l'acció secundària (3.I.2-4):

A la fi aquell home fugí ab gran re d'aur que.l rey li havia comanat per tal que muntiplicás, cor cuydava·s que lo confit qui era en les brustries hagués virtut per la qual l'aur se multiplicava en la fornal. (Llull, Fèlix VI, 36[4].66-68)

\section{I.7 El llibre dels folls (§ $§$ I6-I9) i algunes conclusions}

En la versió de Joan Pasqual, el segon motiu tradicional, el llibre dels folls (J.I37I), s’introdueix amb un altre motiu folklòric molt divulgat per les Mil $i$ una nits: la ronda nocturna del rei, que recorre d'incògnit els carrers de la ciutat per conèixer l’opinió del poble (§ 16 ). En una taverna de Londres, uns vagabunds discuteixen sobre qui és el més eixelebrat de la ciutat: cal remarcar les pinzellades d'ambientació urbana, la recreació de la conversa entre els vagabunds, l'economia amb què expliquen diversos casos de follia (§ I7) i la irrupció inesperada del rei (§ I8). El diàleg entre el rei i el vagabund que l'ha titllat de foll (§ I9) recorre algunes etapes força lògiques. El rei identifica el qui l'ha titllat de foll i l'interroga per saber-ne la raó, perquè ell encara no és conscient d'haver estat víctima de cap engany. L'home li retreu que ha donat un gran tresor a un estafador que no tornarà, però el rei es resisteix a donar-ho per segur. Tota l'escena culmina aleshores amb una resposta tan enginyosa i agosarada com ho ha estat abans l'estafa del fals alquimista: si el mercader no torna, es demostrarà que el rei és foll; si torna, el més foll haurà estat el vagabund, per haver xerrat massa. Com veurem tot seguit, aquesta resposta no és pas l'habitual.

Curiosament, el motiu oriental de la ronda nocturna no apareix pas en el Kaixfal-asrār, com també hi manca, per tant, la discussió sobre els diversos folls de la ciutat i la irrupció sobtada del rei irat. Al-Jawbarī només ens parla d'un home que estén un peculiar registre de babaus i que hi anota en primer lloc el nom del soldà Nūr-ad-Dīn com a “cap dels babaus"; la fama d'aquest títol es divulga, el soldà se n'assabenta i crida l'home a comparèixer davant seu. L'escena de l'interrogatori és l'única, doncs, que té un reflex veritable en la versió de Pasqual (\$ I9). En la versió d’Al-Jawbarī, l'home revela al soldà tot l'ardit de l'estafador i respon al soldà: si el persa torna, caldrà esborrar de la llista el nom del soldà per a posar-hi el del persa - no pas el de l'home que denuncia el frau, com hem vist en Pasqual. El soldà riu i gratifica aquesta rara mostra d'enginy i lucidesa sense adulació:

El més estrany en tot això és que a Damasc hi havia un home que prenia nota dels babaus i sentí aquesta història. N'esbrinà la veritat fent-ne indagacions. Llavors escrigué a l'encapçalament del seu registre: "Nūr-ad-Dīn Mahmūd ibn Zangī, el cap dels babaus". La notícia s’escampà, i ningú no coneixia l'entrellat del cas, però es deia que en Tal havia anotat el sultà com a cap dels babaus, i la 
notícia arribà al visir. Quan el sultà se n'assabentà, digué: -Com ha sabut un pelacanyes tot això, fins al punt que escrigui sobre mi? Porteu-me'l!-. Aleshores la guàrdia el va anar a buscar i, amb el llibre sota el braç, se n’anà amb ells. Quan foren davant del sultà, li va dir: -Tu ets en Tal? -Sí. -I ets tu que anotes els babaus? -Sí. -I m'hi has escrit a mi? -preguntà el sultà. -Sí, si aquest és el teu nom -i l'hi mostrà. -Com és que tu, que ets un plebeu, goses anotar-m'hi? -La qüestió és que vingué a tu un estafador i obrà per a tu una estafa de mil dinars. I agafâ els diners dels musulmans per portarte el tatarboq. Un qualsevol com jo que faig d'escrivà he estat més llest que el que t'ha enganyat-. Quan el sultà sentí les seves paraules, digué: -Si tornés i veiessis que portava el tatarboq amb ell, veuries com obraríem una quantitat d'or inestimable i incomptable. -Oh senyor -digué l'escrivà-, si torna, esborraré el teu nom del capdamunt de la llista i hi escriuré el seu, i no hi haurà en tot el món ningú superior a ell en aquesta matèria, si torna-. Quan el sultà sentí les seves paraules, rigué i digué: -Doneu-li algun diner-. N'hi donaren, i l'escrivent se n'anà. Aleshores, cada vegada que es quedava sense diners, agafava el seu llibre i es posava davant la porta del castell, i quan el sultà s'aparellava per sortir, obria el llibre i deia: -No ha tornat, i aquest és el nom del sultà, fixat i invariable -i es reia d'ell i se'n mofava. I ho va continuar fent fins que es morí el sultà: el foraster no havia tornat. Mira, lector, quin truc i quina audàcia, aquesta de vendre mil dinars per cinc dirhams! (Al-Jawbarī, Kaixfal-asrär IX, 9, pp. 195-96)

Don Juan Manuel tampoc no testimonia el motiu de la ronda nocturna, sinó una variant del registre de babaus. En aquest cas es tracta d'una colla de treballadors que es diverteixen fent llistes de diverses categories de persones i que inclouen el rei en la de "los omnes de mal recado". El rei se n'assabenta - no s'aclareix com-i els convoca amb garanties de seguretat. L'escena de l'interrogatori és anàloga, tot i que resumida, a la d'Al-Jawbarī. Els treballadors no expliquen l'engany del golfín, però cal recordar que ell mateix ha enviat una nota explicativa al rei (vid. supra 3.I.6). Segons el judici dels treballadors, el que és follia és arriscar tants diners sense garanties. Es tracta, justament, de la lliçó general que Patronio vol il-lustrar amb la narració d'aquest exemplum (vid. infra 3.2):

A cabo de algunos días, unos omnes estavan riendo et trebejando, et escribían todos los omnes que ellos conoscían, cada uno de cuál manera era, et dizían: "Los ardides son fulano et fulano; et los ricos, fulano et fulano; et los cuerdos, fulano et fulano". Et assí de todas las otras cosas buenas o contrarias. Et cuando ovieron a escribir los omnes de mal recado, escribieron ý el rey. Et cuando el rey lo sopo, envió por ellos et asseguróles que les non faría ningún mal por ello et díxoles que por quél escrivieran por omne de mal recabdo. Et ellos dixiéronle que por razón que diera tan grand aver a omne estraño et de quien non tenía ningún recabdo. Et el rey les dixo que avían errado, et que si viniesse aquel que avía levado el aver, que non fincaría él por omne de mal recabdo. Et ellos le dixieron que ellos non perdían nada de su cuenta, ca si el otro viniesse, que sacarían al rey del escripto et que pornían a él. (Juan Manuel, Lucanor XX, pp. 84-85)

El motiu oriental de la ronda nocturna proporciona, en canvi, l'analogia més remarcable entre les versions del Zifar i de Joan Pasqual, especialment en el marc narratiu (§§ I6-I8). Malgrat les diferències d'ambientació -el rei moro del Zifar fa la ronda cada dia, i no espia una taverna sinó una casa particular, on una colla de joves es diverteix tot sopant i conversant-, el parentiu és extraordinari: en tots dos textos el rei escolta, de fora estant, mentre els de dins van dient qui és el més foll de la ciutat a parer de cadascun; quan el qui ha plantejat la qüestió designa el rei, la guàrdia irromp bruscament a la sala i el rei, irat, els fa detenir. L'interrogatori té lloc l'endemà, però també comença, com en Pasqual ( $§$ I9), en un to reprensiu i obligant el qui l'ha acusat a identificar-se. A partir d'aquest punt, l'esquema del diàleg i la resposta del jove coincideixen molt més amb el Kaixf al-asrär i amb el Lucanor, i fins i tot s'al-ludeix a un cert "libro de la nesçedat": 
Este rey moro era tan justiçiero en la su tierra, que todas las mas noches andaua con dies o con veynte por la villa a oyr que dezian e que fazian cada vno. Asy que vna noche estauan vna pieça de moros mançebos en vna casa comiendo e beuiendo a grant solas, e el rey estando a la puerta de parte de fuera escuchando lo que dezian. E començo vn moro a dezir: "Diga agora cada vno qual es el mas nesçio desta villa". E cada vno nonbro el suyo. E dixo luego aquel moro mançebo: "Pues el mas nesçio de aquesta villa que yo se, es el rey". Quando el rey lo oyo fue mucho yrado, e mando a los sus omes que los prendiesen e que los guardasen ay fasta otro dia en la mañaña, que gelas leuasen. E porende dizen que quien mucho escucha de su daño oye. E ellos començaron a quebrantar las puertas, e los de dentro demandaron que quien eran. Ellos les dixieron que eran omes del rey. E aquel moro mançebo dixo a los otros: "Amigos, descubiertos somos, ca çiertamente el rey ha oydo lo que nos dixiemos; ca el suele andar por la villa escuchando lo que dizen del. E sy el rey vos feziere algunas preguntas, non le respondades ninguna cosa, mas dexatme a mi, ca yo le respondere”. Otro dia en la mañaña leuaronlos antel rey presos, e el rey con grant saña començoles a dezir: "Canes, fijos de canes, que ouistes comigo en dezir que yo era el mas nesçio de la villa? Quiero saber qual fue de vos el que lo dixo". "Ciertas", dixo aquel moro mançebo, "yo lo dixe". "Tu?", dixo el rey: "dyme por que cuydas que yo so el mas nesçio". "Yo te lo dire", dixo el moro. "Señor, sy alguno pierde o le furtan alguna cosa de lo suyo por mala guarda, o dize alguna palabra errada, nesçio es porque non guarda lo suyo, nin se guarda en su dezir; mas avn non es tan nesçio commo aquel que da lo suyo do non deue, lo que quiere perder a sabiendas asy commo tu feziste. Señor, tu sabes que vn cauallero estraño vino a ti, e porque te dixo que te faria oro de plomo, lo que non puede ser por ninguna manera, distele dies camellos cargados de plata con que conprase los poluos para fazer oro. E crey çiertamente que nunca le veras mas ante ty, e sy as perdido quantol diste, e fue grant mengua de entendimiento". "E sy veniere?", dixo el rey. "Cierto so, señor", dixo el moro, "que non verna por ninguna manera". "Pero sy veniere?", dixo el rey. "Señor”, dixo el moro, "sy el veniere, raeremos el tu nonbre del libro de la nesçedat e pornemos y el suyo; ca el verna a sabiendas a grant daño de sy, e por auentura a la muerte; porque el non podra fazer aquello que te prometio, e asy sea el mas nesçio que tu”. (Zifar, pp. 405-406)

Certament, el plantejament del relat (3.I.I) ens demostra que Joan Pasqual no pot haver readaptat la seva versió de l'exemplum a partir del model del Zifar, però l'anàlisi d'algunes seqüències anteriors també ens ha permès de constatar nombroses afinitats entre aquests textos (3.I.2-6), que ara trobem confirmades en la sequiència final (3.I.7). Tot i que el Zifar és un text conegut a Catalunya ${ }^{20}$ la hipòtesi d'un antecedent comú a les versions del Zifar i de Pasqual és la millor explicació d'aquestes innovacions compartides, que els oposen als testimonis de don Juan Manuel i Al-Jawbarī. En concret, sembla que cal atribuir a un antecedent comú, i no pas a la llibertat creadora de l'Anònim o de Pasqual, la iniciativa d'introduir la ronda nocturna del rei com a recurs narratiu per a recollir les enraonies del poble. D'altra banda, cal observar que la figura de l'excèntric que fa l’inventari dels folls en el Kaixf al-asrär també manca en la versió del Lucanor, on és substituïda per una colla de treballadors que riuen i escriuen, és a dir, 'fan llistes'. Aquesta lleugera incongruència també sembla l'indici d'una innovació atribuïble a l'arquetip hipotètic dels tres testimonis hispànics. Joan Pasqual és l'únic de tots tres que depura tota referència a l'escriptura, modificant el dictum final del vagabund en un sentit completament nou.

L’home que compilava el llibre dels folls sí que perviu, en canvi, en la tradició independent del segon motiu tradicional, testimoniada per primera vegada en el Novellino Borghini. La seva versió, com hem dit, es pot remuntar molt probablement a un testimoni de la segona dècada del segle XIV

20. El 27 d'octubre de I36r el rei Pere el Cerimoniós reclama sense dilació al fidel aragonès Eiximeno de Mont-real un "librum militis vocati Siffar" que havia de fer copiar d'un exemplar de l'obra i portar a Barcelona, per tal com "dictus liber sit nobis multipliciter opportunus” (Rubió I9o8-2I, I, I96, doc. I99; Cingolani I990-9I, 93). 
(Lo Nigro I963, 33I), i està explícitament relacionada amb l’alquímia:

Uno s'era messo a scrivere tutte le follie e le scipidezze che si facessero. Scrisse d'uno che s'era lassato ingannare a uno alchimista, perché, per uno, gli avea renduto il doppio di quello che gli avea dato, e, per raddoppiare più in grosso, gli diede cinquanta fiorini d'oro; ed egli se n'andò con essi. Andando questo ingannato a lui, e domandando perché l'avea schernito così, e dicendo: -Se egli mi avesse renduto il doppio, come dovea ed era usato, che avrebbe scritto? -rispose: -Avere'ne tratto te, e messovi lui (Novellino Borghini LXXIv, p. 335).

Aquesta brevíssima novella ofereix una versió anàloga a la d'Al-Jawbarī, tot i que rigorosament esquemàtica, amb omissió dels elements circumstancials. La víctima de l'engany és un personatge indeterminat, no pas un rei, i, d'altra banda, l'alquimista ha fingit un fenomen de multiplicació de l'or, com en el Fèlix de Ramon Llull - una coincidència molt particular i, potser, significativa. Fora d'això, el diàleg conserva tots els elements essencials que culminen en el dictum final.

Pel que fa a la vinculació d'aquest text amb la tradició del fals alquimista, és molt probable que hom hagués aïllat el segon motiu directament del Kaixf al-asrār o bé d'un altre model que hagués conservat la figura de l'escrivent del llibre dels folls: un antecedent del Kaixf al-asrār o bé un descendent; en tot cas, però, un model (diguem-ne $\alpha$ ) diferent del possible antecedent (diguem-ne ß) comú al Lucanor, al Zifar i a Joan Pasqual, i també diferent del probable antecedent (diguemne $\gamma$ ) comú a aquests dos darrers testimonis. D’altra banda, no sembla impossible que el Fèlix de Ramon Llull, que també descriu un fenomen de multiplicació, pogués davallar d'aquell mateix antecedent $\alpha$, potser consistent en una redacció molt esquemàtica de la versió extensa del nostre conte, composta en la segona meitat del segle XIII. El fet que Llull parli de dobles i el Novellino Borghini de florins no contradiria aquesta possibilitat. Aquesta possibilitat no sembla prevista dins l'stemma narrationum de Fradejas Lebrero (2OOI, II6), que insereix el Novellino -juntament amb tots els altres textos que només transmeten el llibre dels folls- en una branca descendent d'AlJawbarī, però estrictament separada dels altres testimonis.

Només l'aparició de nous testimonis, orientals i occidentals, ens podria aportar arguments decisius per a confirmar l'existència d'aquestes dues famílies $\alpha$ i $\beta$, així com la possibilitat que totes dues davallin d'un arquetip (diguem-ne $\omega$ ) comú al conjunt de la tradició europea. Fins i tot en aquest cas, també resultaria molt difícil d'establir la relació entre aquest hipotètic arquetip $\omega$ i el testimoni del Kaixf al-asrär. Malgrat la temptació de postular-ne una traducció -llatina o romànica, en particular castellana- datable a mitjan segle XIII, no podem descartar la possibilitat que l'hipotètic $\omega$ i el Kaixf al-asrär fossin descendents d'un model oriental comú.

\subsection{Marc narratiu i lliçó moral}

Diversos testimonis d'un mateix exemplum poden oferir una notable diversitat d'aplicacions didàctiques. En el marc del Tractat de les penes particulars d'infern, Joan Pasqual narra l'exemplum del fals alquimista per demostrar que l'alquímia és un frau mereixedor d'una pena particular a l’infern, entre els fraus fets en la cosa. Per contra, en un context enciclopèdic com el llibre VI del Fèlix o Llibre de meravelles, dedicat precisament als metalls, la intenció de Llull és confirmar que la transmutació de metalls és impossible i que l'alquímia és una estafa que s'aprofita de la cobdícia dels incauts:

-Senyer - dix Felix al philosof-, segons vostres paraules par que vos digats que inpossible cosa sia fer transmutaçió de un element en altre ni de un metall en altre segons l'art de alquimia, cor deyts que negun metall no ha apetit de mudar son esser en altre esser; cor si mudava son esser en altre 
esser no seria aquell esser matex lo qual ama esser. On be he enteses totes vostres rahons e totes vostres semblançes; mas de.$^{\mathrm{a}}$. cosa me maravell fortment, ço és a saber, com pot hom haver tan gran afecció a la art de la alquimia, si la art no es vera. (Llull, Fèlix VI, 36[4].47-54)

El Libro del caballero Zifar integra en la seva estructura de novel-la de cavalleria tot un enfilall de narracions exemplars amb funció didàctica. Al llibre IV, l'emperador de Trigrida demana a l'infant Roboán que l'aconselli a propòsit d'un físic que promet de guarir qualsevol malaltia amb tres herbes medicinals de gran virtut, però que no vol revelar-ne l'origen ni permetre que ningú vagi a cercarles sinó ell. Aquestes herbes equivalen a l'ingredient desconegut del fals alquimista, i per això l'infant n'explica l'exemple com a consell de cautela. En un recull exemplar com el Libro del conde Lucanor, Patronio aconsella el comte sobre una proposta d'inversió que li garanteix un benefici tan extraordinari com és el dècuple del capital inicial. Al final de cada exemple, Roboán i Patronio coincideixen en la lliçó moral (la cursiva és meva):

"E porende señor”, dixo el infante Roboan al enperador, “commoquier que seades muy rico, e podiesedes enplear muy grant auer en tan noble cosa commo aquesta que vos dize este fisico, sy verdat puede ser, non me atreuo a vos consejar que auenturedes tan grant auer; ca sy vos fallesçiese, dezirvos yan que non abiedes fecho con buen consejo nin con buen entendimiento; ca grand mengua de entendimiento es auenturar ome grant auer en cosa dudosa; ca finca engañado sy lo non acaba, e con perdida". "Chertas", dixo el enperador, "tengome por bien aconsejado de vos". (Zifar, pp. 406)

"Et vós, señor conde Lucanor, si queredes que non vos tengan por omne de mal recabdo, non aventuredes por cosa que non sea cierta tanto de lo vuestro que vos arrepintades si lo perdierdes, por fuza de aver grand pro, seyendo en dubda".

Al conde plogo deste consejo, et fízolo assí et falló se dello bien. Et veyendo don Johán que este exienplo era bueno, fízolo escribir en este libro et fizo estos viessos que dizen assí:

Non aventuredes mucho la tu riqueza

por consejo del que ha grand pobreza. (Juan Manuel, Lucanor XX, p. 85)

Noteu que els versos finals del comte Lucanor, coherents amb la nota que el golfín envia al rei de mal recapte (3.I.6), vehiculen una lliçó diferent de la de Patronio.

El Kaixf al-asrār d'Al-Jawbarī també pretén d'il-lustrar explícitament una lliçó de prudència, però no exactament aquesta, i sobretot vol referir una estafa admirable per la seva audàcia, habilitat i enginy: "Per revelar un dels secrets més grans em detindré en el que li succeí al sultà, rei de reis, el just Nūr-ad-Dīn ibn Zangī, que Déu el prengui en la seva misericòrdia. A continuació es conta una narració que es podria escriure amb lletres d'or" (IX, 9, p. I88). Fins i tot fa una lloança del risc: "Com se sol dir, "qui arrisca quelcom de valuós, obté quelcom de valuós”" (p. I89). Sembla, doncs, que la coincidència entre les lliçons morals de Roboán en el Zifar i de Patronio en el Lucanor és atribuïble a una relació d'influència entre aquests textos, gairebé coetanis, o bé a un antecedent comú, com ara els hipotètics $\beta$ o $\omega$ que hem apuntat al final de l'apartat anterior (3.I.7). Cal considerar, realment, molt improbable que es tracti d'una innovació diguem-ne "poligenètica": no solament per les coincidències d'expressió, sinó també perquè la lliçó de cautela compartida per Roboán i Patronio -arriscar un gran capital en una empresa incerta o dubtosa és una follia, perquè en l'afany d'obtenir un gran guany es podria perdre tot- no és pas la lliçó més òbvia que es desprèn d’aquest conte -l'alquímia és una estafa.

Ara bé, tot i que no és la lliçó moral més òbvia que se’n podria treure, aquesta lliçó de cautela, contra les inversions prometedores però molt arriscades, és anàloga a la que proposa la rúbrica del Novellino Borghini: "Qui conta di certi che, per cercare del meglio, perderono il bene" (Lo Nigro 
ed. I963, 335). La coincidència no em sembla pas casual, sinó un indici més a favor de l'existència hipotètica dels arquetips $\omega$ i $\beta$ : l'arquetip $\omega$, molt semblant al conte d'Al-Jawbarī, hauria proposat la insensatesa del rei com un lliçó de prudència contra les inversions arriscades. Aquesta moral s'hauria transmès, d'una banda, a l'hipotètic $\alpha \mathrm{o}$, si més no, al testimoni que coneixem gràcies al Novellino Borghini; de l'altra, a $\beta$, antecedent hipotètic dels tres testimonis de la versió extensa. I aquesta mateixa moral també degué figurar explícitament en l'antecedent $\gamma$ del Zifar i de Pasqual, tret que Roboán hagués manllevat la seva lliçó moral del Lucanor -tot i que això implicaria que l'Anònim coneixia l'exemple de l'alquimista per diverses fonts.

\section{Originalitat i tradició en Thecanon's yeoman's tale de Chaucer}

$\mathrm{L}$ a "Pars secunda” de The canon's yeoman's tale de Geoffrey Chaucer (Canterbury tales VIII [G], vv. 972-I48I) explica l'estafa infligida a un capellà de Londres per un canonge regular tan ben dotat per a l'engany i la prestidigitació que no li cal inventar-se cap ingredient desconegut per a introduir les llimadures de metall preciós dins el gresol: ell mateix és capaç de fer-ho, amb habilitat i tota mena d'astúcies, davant el nas de la víctima. El benefici fraudulent del canonge consistirà en la venda, molt lucrativa, d'una fórmula magistral o preparació secreta, imprescindible per a la transmutació alquímica, que al capellà, evidentment, no li funcionarà. El conte de Chaucer pot prescindir, per tant, no solament del llibre dels folls (3.I.7), sinó també dels episodis que en el motiu tradicional del fals alquimista es relacionen amb l'adquisició de l'ingredient exòtic: l'acció secundària entorn de l'especier (3.I.2-4) i la fugida a l'estranger amb el capital destinat a l'aprovisionament (3.I.6). El que en resta és, bàsicament, una narració molt amplificada de l'escena de la demostració (3.I.5), tot i que els altres episodis han pogut deixar nombrosos vestigis escampats no tan sols en aquesta "Pars secunda", sinó també en el pròleg (vv. 554-7I9) i en la "Prima pars" (vv. 720-97I), que emmarquen les revelacions del narrador: el yeoman o criat, ja tip i escarmentat, d'un altre canonge també dedicat ruïnosament a l'alquímia i el frau. Molts d'aquests vestigis han estat assenyalats i analitzats per Serrano Reyes (I996, 25I-368) mitjançant una minuciosa comparació entre el conte de Chaucer i els testimonis del Fèlix, del Zifari, sobretot, del Lucanor. Sense tenir en compte l'estudi de Marsan (I974) ni el precedent del Kaixf al-asrār, aquesta anàlisi pretén d'argumentar una possible influència directa, narrativa i textual, del Lucanor, que Chaucer pogué conèixer el s367 durant un probable viatge a Castella fins a Santiago de Compostel-la. Una influència hipotètica que avui cal posar en qüestió.

L'extensa narració de l'estafa comença amb la presentació del capellà, ric i beneit, i del canonge regular, tot un dimoni amb fama de savi que atreu de lluny moltes víctimes (vv. 972-9I). Però, a diferència del fals alquimista del motiu tradicional, el canonge no confirma aquesta fama fent ostentació d'opulència (3.I.I), sinó que es guanya la plena confiança del capellà retornantli puntualment un deute (vv. 992-IO4I). Tot seguit, per correspondre a la gentilesa del capellà, s'ofereix a ensenyar-li la manera d'obrar la transmutació alquímica (vv. IO42-64), en una altra variant de l'episodi tradicional (3.I.2) també testimoniat per un exemplum anterior del Kaixf al-asrär (IX, 8, pp. I82-183). El capellà s'hi engresca immediatament sense ni un bri de desconfiança, en fort contrast amb l'hostaler que, en el pròleg, sí que desconfia de la filosofia alquímica del canonge molt mal vestit que arriba acompanyat del criat (vv. 627-639), d'acord amb la mateixa lliçó tòpica que don Juan Manuel vehicula amb la nota del golfín (3.I.6) i amb els versos finals (3.2). En efecte, just en aquest punt, el criat-narrador introdueix una digressió moral (vv. Io65-87) per a glossar l'estúpida ingenuïtat del capellà -encegat per la cobdícia, incapaç de sospitar amb qui fa negocis-, en la qual 
s'entreveu un possible vestigi del motiu tradicional del llibre dels folls (3.I.7). ${ }^{21}$

Un servidor del capellà participa en els preparatius de la demostració (vv. IIO2-43), però, a diferència del criat o majordom d'Al-Jawbarī o del secretari de Pasqual, només és enviat a comprar tres unces d'argent viu o mercuri i se li demana que porti carbó. Mentrestant, el canonge es treu un gresol i -per incrementar la confiança de la víctima, conforme a l'esquema tradicional i, especialment, el Kaixf al-asrār (3.I.5) - l'allarga al capellà perquè realitzi l'experiment amb les seves pròpies mans: mortificant l'argent viu, obtindrà un argent de la màxima puresa i mal-leable (vv. II25-30). El canonge afirma que el secret de la seva alquímia són unes pólvores que ha comprat molt cares -com l'ingredient exòtic d'Al-Jawbarī-, tot i que el criat-narrador aclarirà de seguida que, en realitat, es tracta d'un material qualsevol, sense valor, només per a enganyar. ${ }^{22}$ Chaucer ha prescindit del truc tradicional, però aquestes pólvores tan cares són, com observa Serrano Reyes (I996, 267268), un ressò de l'especier omès (3.I.3), i serviran per a justificar l'elevat preu de la fórmula final.

Per a dur a terme la demostració (vv. II44-242), la primera condició del canonge és fer sortir el servidor i tancar la porta perquè tot sigui secret -en realitat, perquè altres ulls no puguin descobrir els seus jocs de mans-; la segona, que el capellà s'encarregui de totes les operacions perquè vegi clar que no hi ha truc -en realitat, per a tenir-lo distret. Mentre el capellà bufa el foc, el canonge es treu de la màniga un carbó amb un forat farcit de llimadures d'argent i tapat amb cera que, com ens aclareix el narrador, ja duia preparat d'abans, com les altres coses que farà servir en els trucs successius. ${ }^{23}$ Serrano Reyes (I996, 26I-64) també assenyala aquests versos com un vestigi de la preparació prèvia de l'ingredient exòtic en els contes anàlegs (3.I.I). El canonge deixa caure el carbó dins el gresol mentre el capellà s'eixuga la suor de la cara; després fabricaran una lingotera de guix i obtindran un lingot d'argent -com el lingot d'or d'Al-Jawbarī (3.I.5) o el "bell carrell de fin aur” de Pasqual (§ I 4 ) - que farà exultar el capellà. ${ }^{24}$ La demostració es repeteix com en l'esquema tradicional (3.I.5), però en el conte de Chaucer (vv. I243-330) el canonge practica ardits diferents en cada cas, primer dipositant les pólvores d'argent dins el gresol mitjançant un bastó buit tapat amb cera que farà servir per a remenar els carbons, i després substituint un lingot de coure per un tercer lingot d'argent - tots tres són d'una unça, d'acord amb la quantitat de mercuri adquirida pel servidor. El canonge proposa de portar els tres lingots a un orfebre perquè en certifiqui la puresa i, novament, el capellà exulta, en una escena que té un notable paral-lel en el text de Joan Pasqual. ${ }^{25}$ No obstant això, cal remarcar que els dos primers artificis practicats pel canonge -el del carbó i el del bastó (tenalles o molls) farcits d'argent i tapats amb cera- tenen un paral-lel ben precís en altres contes recollits per Al-Jawbarī en el Kaixf al-asrär (IX, I-4, pp. I74-78) que Chaucer, sens dubte,

2I. Cf. vv. IO74-IO77, I082-I085: "Noght wiste this preest with whom that he delte, / Ne of his harm comynge he no thyng felte. / O sely preest! O sely innocent! / With coveitise anon thou shalt be blent! / [...] / Wherfore, to go to he conclusion, / That refereth to thy confusion, / Unhappy man, anon I wol me hye / To tellen thyn unwit ant thy folye..."

22. Cf. vv. II33-35: "I have a poudre heer, that coste me deere, / Shal make al good, for it is cause of al / My konnyng...", però vV. II47-5I: "And this chanoun into the crosselet caste / A poudre, noot I wherof that it was / Ymaad, outher of chalk, outher of glas, / Or somwhat elles, was nat worth a flye, / To blynde with this preest...”

23. Cf. vv. ir65-68: "And understondeth that this false gyn / Was nat maad ther, but it was maad bifore; / And othere thynges I shal tellen moore / Herafterward, whiche that he with hym broghte".

24. Cf. vv. I240-62: "He putte his hand in and took up a teyne / of silver fyn, and glad in every veyne / Was this preest, whan he saugh it was so."

25. Cf. vv. I337-4I: "Unto the goldsmyth with thise teynes three / They wente and putte thise teynes in assay / To fir and hamer; myghte no man seye nay, / But that they weren as hem oghte be. / This sotted preest, who was gladder than he?"; Pasqual, Tractat de les penes particulars d'infern XLVI, § I4: “Lo rey mane al secretari que vage per los millors argenters de Londres, e tots dihen que és pus fin aur que lo noble de nau. Lavors lo rey fou molt alegres e féu gran festa al alquimiayre". Aquesta coincidència podria ésser casual, atès que la verificació experta de la puresa del metall és el millor recurs per a reforçar la credulitat de la víctima. 
coneixia.

L'estafa culmina, no pas amb una fugida (3.I.6), sinó amb la venda per quaranta lliures d'aquella fórmula o recepta ("receit") tan cara (vv. $1350-67$ ) que el canonge ha presentat abans com a causa de tot el seu coneixement alquímic. Chaucer equipara irònicament els perills que amenacen els alquimistes, segons la literatura alquímica, i els que amenacen els estafadors; així, el canonge prega al capellà que no divulgui la fama de la seva ciència, perquè li farien la pell (vv. I368-80). Tot seguit se’n va i no es deixarà veure mai més, perquè la preparació alquímica és inútil. En aquest punt Serrano Reyes (I996, 295-96) ha assenyalat la coincidència textual més remarcable amb el Lucanor, tot i que insuficient per a deduir-ne una influència directa. ${ }^{26}$ Don Juan Manuel també ha al.ludit abans a una "recepta" que el rei ha provat i doblat amb èxit fins a exhaurir el tabardie (3.I.5), i és només llavors que el golfín fuig amb l'or confiat per a adquirir-ne més.

La "Pars secunda" s'acaba amb una admonició moral (vv. I380-427) adreçada principalment als interessats en l'alquímia i corroborada amb autoritats esotèriques (vv. I428-8I): deixeu-ho córrer, perquè en aquest afer no hi guanyareu res, sinó que hi perdreu tot el que teniu i més. ${ }^{27}$ Aquesta lliçó no demostra ni exclou cap relació de parentiu amb la moral de la rúbrica del Novellino Borghini, ni tampoc amb la de Patronio i Roboán en els testimonis castellans (3.2), perquè Chaucer insereix el seu conte en un marc didàctic molt desenvolupat i explícit, que s'amplifica encara més en el pròleg (vv. 554-7I9) i en la "Prima pars" (vv. 720-97I) recollint tots els tòpics de la controvèrsia antialquímica. Aquest marc didàctic no es presenta com el consell d'un cortesà al seu senyor, sinó com una revelació de secrets -com el Kaixf al-asrār d'Al-Jawbarī-amb què el criat d'un altre canonge alquimista vol desenganyar tothom i mostrar que l'alquímia és una ruïna i un frau: fastiguejat del seu amo, ja no el farà callar ningú amb l'excusa de l'hermetisme (vv. 684-7I9). ${ }^{28}$

Després d'afirmar que el seu amo fóra capaç de pavimentar el camí d'or i argent (v. 626), la rèplica de l'hostaler, conforme al tòpic - per què, doncs, no es vesteix més decentment? (vv. 62O$3^{8}$ )-, incita el criat a la confessió (vv. 639-55). Fan vida ravalera i es migren la salut sense assolir mai el fi de l'opus; tot el que fan és enganyar molta gent, manllevant or i fent creure que poden doblar la quantitat invertida, ${ }^{29} \mathrm{i}$, encara que tot és fals, els alquimistes no perden mai aquella esperança que els reduirà a la misèria més absoluta (vv. 656-83). Serrano Reyes (1996, 286-290, 298-99) ha relacionat la falsa multiplicació al-ludida en aquest passatge amb l'estafa del Fèlix -i del Novellino- i amb la proposta de negoci que motiva el consell de Patronio al comte Lucanor.

En la "Prima pars", la confessió o admonició moral -tothom qui es doni a l’alquímia ho perdrà tot com nosaltres i induirà els altres a caure-hi (vv. 720-749) - es complementa amb una revelació

26. Cf. vv. I38I-87: "He wente his wey, and never the preest hym sy / After that day; and whan that this preest shoolde / Maken assay, at swich tyme as he wolde, / Of this receit, farwel! It wolde nat be. / Lo, thus byjaped and bigiled was he! / Thus maketh he [sc. the canon] his introduccioun, / To brynge folk to hir destruccioun"; Lucanor, p. 84: "Et desque el golfín lo tovo en su poder, fuesse su carrera et nunca tornó al rey. Et assí fincó el rey engañado por su mal recabdo”; Zifar, p. 405: "E el cauallero tomo su auer e fuese, con entençion de non tornar mas nin de se poner en lugar do el rey le podiese enpesçer"; Pasqual, Tractat de les penes particulars d'infern XLVI, § I5: "E lo mercader ab la companyia e ab la peccúnia anà-sse'n en tal punt que may no tornà. E lo rey tostemps sperava, e bé podia sperar. Aquest fóu bona alquímia!". La coincidència en una locució freqüent, fins i tot en llatí (viam suam ivit), no té valor demostratiu.

27. Cf. vv. I4OO-4O2, I42I-22: "A man may lightly lerne, if he have aught, / To multiplie, and brynge his good to naught! / Lo!, swich a lucre is in this lusty game [...] / Ye shul nothyng wynne on that chaffare, / But wasten al that ye may rape and renne" .

28. Cf. vv. 7OO-7O2: "And whan this Chanon saugh it wolde nat bee, / But his Yeman wolde telle his pryvetee, / He fledde awey for verray sorwe and shame."

29. Cf. vv. 673-77: "To muchel folk we doon illusioun, / And borwe gold, be it a pound or two, / Or ten, or twelve, or manye sommes mo, / And make hem wenen, at the leeste weye, / That of a pound we koude make tweye”. 
dels rudiments de l'ars alchemica. $3^{\circ}$ Aquesta "didàctica tècnica" produeix el mateix efecte de versemblança satírica que la precisió científica amb què s'expliquen els trucs del fals alquimista en alguns testimonis de la tradició, especialment en el Zifar i en Pasqual (3.I.5), però també en el conjunt del capítol IX del Kaixf al-asrār. El criat descriu la pràctica de l'opus (vv. 755-779) enumerant-ne ingredients, procediments i fenòmens - evaporació dels volàtils, sedimentació dels sòlids-, però tot és en va, tot és perdut (vv. 777, 780-83). Després amplia la informació sobre substàncies, herbes, preparats i instrumental de laboratori (vv. 784-818), i enumera les quatre substàncies volàtils: mercuri, orpiment, amoníac i sofre (vv. 82O-24); els set metalls corresponents als set planetes (vv. 825-29), i, més avall, alguns tractaments (vv. 852-6I). Aquesta ciència és una follia i s'hi perd tot (vv. 830-5I); la cerca de l'elixir és una esperança vana que redueix l'alquimista a la misèria (vv. 862-97) perquè, encara que els experiments resultin sempre fallits, siguin molt perillosos i acabin en baralles, els alquimistes persisteixen en el deliri i la follia, malgrat l'aparença de savis (vv. 898-970), i diuen que cal invertir-hi tot el bé que posseeixen. En aquest punt Serrano Reyes $(\mathrm{I} 996,355)$ assenyala un altre possible ressò textual, ara de la lliçó moral de Patronio en el Lucanori de Roboán en el Zifar..$^{3 \mathrm{P}}$ Però cal recordar que Al-Jawbarī afirma, tot ponderant l'audàcia del seu protagonista, que "qui arrisca quelcom de valuós, obté quelcom de valuós" (3.I.3). O que la rúbrica del Novellino Borghini es refereix als qui "per cercare del meglio, perderono il bene" (3.2), com passa de vegades als mercaders, tal com diuen els alquimistes de Chaucer per encoratjar-se. ${ }^{32}$

A parer meu, resulta evident que, entre les diverses fonts alquímiques de què Chaucer disposava, hi havia, si més no, un testimoni del conte tradicional del fals alquimista i el rei, que probablement incloïa el motiu del llibre dels folls i una aplicació moral com la que il-lustren el Novellino Borghini i els dos testimonis castellans. Molt probablement es tractava d'una versió molt pròxima al testimoni del Kaixf al-asrār d'Al-Jawbarī, i potser contenia algunes de les peculiaritats que ens ha semblat reconèixer en els exempla de don Juan Manuel i de Joan Pasqual -com ara la verificació dels lingots de producte alquímic a càrrec d'avaluadors experts-, però no podem afirmar que el Lucanor ni cap altre dels testimonis coneguts hi hagi exercit una influència directa. A més a més, hem constatat que Chaucer també coneixia alguns dels altres fraus alquímics que Al-Jawbarī recull en el capítol IX del Kaixf al-asrär. Des del punt de vista d'un stemma hipotètic, considero, doncs, molt probable que The canon's yeoman's tale sigui un descendent de l'arquetip $\omega$ o, fins i tot, de $\beta$ (3.2). Chaucer manipula el material tradicional amb la màxima llibertat inventiva, compositiva i expressiva, $\mathrm{i}$ desdibuixa inevitablement les relacions de parentiu.

\section{Cap a un stemma de la tradició}

La comparació del nou testimoni de Joan Pasqual amb el Kaixf al-asrār d'Al-Jawbarī i amb el conjunt dels testimonis més antics d'aquest motiu exemplar ens ha proporcionat alguns indicis importants d'agrupació.

Raméline Marsan (I974, 39I) havia relacionat el Fèlix de Llull amb una redacció diferent de la

3o. Per al context i les possibles fonts, implícites o explícites, d'aquests passatges expositius, remeto als textos i la informació bibligràfica que proporcionen Collette-DiMarco 2005, 7I6-24 i 739-47.

3I. Cf. v. 946: "Us moste putte oure good in aventure"; Zifar, p. 406: "non me atreuo a vos consejar que auenturedes tan grant auer [...] grand mengua de entendimiento es auenturar ome grant auer en cosa dudosa; ca finca engañado sy lo non acaba, e con perdida"; Lucanor, p. 85: "non aventuredes por cosa que non sea cierta tanto de lo vuestro que vos arrepintades si lo perdierdes, por fuza de aver grand pro, seyendo en dubda”.

32. Cf. v. 947-50: "A marchant, pardee, may nat ay endure, / Trusteth me wel, in his prosperitee. / Sometyme his good is drowned in the see, / And somtyme comth it sauf unto the londe". 
d'Al-Jawbarī i els testimonis castellans: no solament per la brevetat de la seva narració i l'omissió dels llibre dels folls, sinó sobretot perquè el procediment de l'engany no consisteix en una transmutació, sinó en una multiplicació. Tot i que la versió de Llull conté un ingredient misteriós, concretament "tres brusties, en les quals havia decocçió de erbes et era aquella decocçió en semblant de letovari" (3.I.I), el fals alquimista no fuig amb uns diners destinats a comprar-ne més, sinó amb l’or destinat a la multiplicació. Aquestes innovacions són presents en la novella LXXIV del Novellino Borghini: "perché, per uno, gli avea renduto il doppio di quello che gli avea dato, e, per raddoppiare più in grosso, gli diede cinquanta fiorini d'oro; ed egli se n’andò con essi” (3.I.7). És molt probable, doncs, que les peculiaritats de la versió de Llull no s’hagin d'atribuir a la seva creativitat, sinó a un possible antecedent $\alpha$ compartit amb el Novellino Borghini, que hauria contingut, potser en una forma esquemàtica, els dos motius tradicionals que integren el conte d'Al-Jawbarī. L'stemma dissenyat per Fradejas Lebrero (200I, II6) excloïa explícitament aquesta possibilitat.

Marsan (I974, 392-93) relacionà el Lucanor directament amb el Kaixf al-asrär tenint en compte que la seva seqüència narrativa és gairebé idèntica, tot i que abreujada, i que designa amb el nom de tabardíe l'ingredient desconegut que Al-Jawbarī anomena tatarboq o tabarmukk i l'Anònim del Zifar alexandrique; no es pronuncià, en canvi, respecte de les fonts del Zifar, atès que les seves discrepàncies podrien atribuir-se tant a l'originalitat de l'Anònim com a una diferència de model. Una de les coincidències remarcades per Serrano Reyes (1996, 270-7I) per a parlar del Zifar com a font de don Juan Manuel -amb una perspectiva distorsionada pel desconeixment del Kaixf al-asrär i de les observacions de Marsan- és el marc narratiu: tots dos posen l'exemplum del fals alquimista en boca d'un cortesà (Roboán o Patronio) que dóna consell a un senyor (l'emperador de Trigrida o el comte Lucanor) a qui es proposa una inversió arriscada. La coincidència és remarcable, i fa pensar en un possible antecedent $\beta$ comú als dos testimonis castellans, especialment si es considera la lliçó moral que enuncien Roboán ("non me atreuo a vos consejar que auenturedes tan grant auer”, "grand mengua de entendimiento es auenturar ome grant auer en cosa dudosa; ca finca engañado sy lo non acaba, e con perdida") i Patronio ("non aventuredes por cosa que non sea cierta tanto de lo vuestro que vos arrepintades si lo perdierdes, por fuza de aver grand pro, seyendo en dubda”); el fet que la rúbrica del Novellino Borghini proposi una lliçó semblant abona la hipòtesi d'un arquetip $o$ antecedent $\omega$ comú als subarquetips hipotètics $\alpha$ i $\beta$ (3.2). En el cas que Llull hagués partit d'un model com ara l'hipotètic $\alpha$, hauria prescindit d'aquesta aplicació moral juntament amb el motiu del llibre dels folls.

La hipòtesi d'una influència directa del Lucanor sobre The canon's yeoman's tale (Serrano Reyes I996) no sembla tan probable com l'afirmació que Chaucer conegué un model afí al Kaixf al-asrār, amb algunes característiques que manquen en el text de don Juan Manuel. El text de Chaucer, inserit en un marc amb una intenció didàctico-satírica molt accentuada i desenvolupada, davalla molt probablement de l'arquetip hipotètic $\omega$, o potser de $\beta$; testimonia un coneixement d'altres fraus continguts en el capítol IX del Kaixf al-asrār, i representa l'adaptació més lliure de l'esquema tradicional.

Joan Pasqual no insereix l'exemplum de l'alquimista en el Tractat de les penes particulars d'infern per a il-lustrar un consell de prudència, però el seu testimoni també podria comptar-se entre els descendents del subarquetip $\beta$. Malgrat el canvi d'ordre d'una escena-la venda de l'ingredient desconegut a l'especier (3.I.3) -, la seva seqüència narrativa és paral-lela a la del Kaixf al-asrār, més completa que la del Lucanor en l'acció secundària -l'adquisició de l'ingredient desconegut (3.I.2-4) - i més fidel que la del Zifar en el plantejament inicial: l'arribada a Anglaterra, l'ostentació d'opulència, l'hostaler que facilita el primer contacte amb el rei -com el visir d'Al-Jawbarī, que manca en els dos testimonis castellans-, etc. (3.I.I). Entre les nombroses afinitats que l'emparenten amb el Zifar-les característiques de l'especier (3.I.3), la precisió amb què descriu els fenòmens 
físics que produeixen el truc de la transmutació (3.I.5) -, la més significativa és el recurs final al motiu oriental de la ronda nocturna del rei (3.I.7). Joan Pasqual parteix d'un model més pròxim al Kaixf al-asrär que el mateix Zifar, per tant, totes aquestes afinitats no reflecteixen una influència directa, sinó que indiquen l'existència molt probable d'un antecedent comú $\gamma$. Sembla, en canvi, que podem atribuir a la creativitat de Pasqual algunes altres peculiaritats de la seva narració, com ara l'omissió del "nom innot" de l'ingredient que el secretari reial consulta debades en el Vocabularium de Papies i en el Catholicon de Giovanni Balbi (§ Io); alguns canvis d'ordre (§§ II i, sobretot, I2), i moltes de les circumstàncies que aporten concreció urbana i geogràfica, i al capdavall versemblança, a l'exemplum tradicional, com ara la seva possible connexió amb la llegenda alquímica de Ramon Llull i la cort d'Anglaterra (vid. п i 3.I.I). Algunes coincidències particulars amb The canon's yeoman's tale de Chaucer (vid. nn. 24 i 25) no són prou concloents per a considerar-les un reflex de models comuns.

Atesa la manca d'indicis prou fiables, no considero oportú d'especular sobre possibles llengües (llatí, castellà, occità, català, italià) i llocs de redacció (Toledo, Montpeller, Salerno) d'aquests quatre arquetips hipotètics. Tampoc no sabem si el probable arquetip $\omega$ consistia en una traducció del text del Kaixf al-asrär o d'un altre antecedent oriental. Pel que fa a la cronologia, $\omega$ i $\alpha$ haurien d'haver estat anteriors al Fèlix de Ramon Llull (ı288/89), $\beta$ anterior al Libro del conde Lucanor de don Juan Manuel, del primer terç del segle XIV (a. I335), i $\gamma$ anterior al Libro del caballero Zifar, del segon quart del XIV (I32I/5o).

La probable existència d'una tradició oral, la intervenció activa de la memòria, els efectes impredictibles de la contaminació narrativa i, sobretot, la llibertat creativa dels autors impedeixen d'aplicar a la literatura comparada un mètode demostratiu anàleg al de l'ecdòtica. Però, malgrat la incertesa d'algunes conclusions, resulta ben clar que comparar el conjunt dels testimonis anàlegs d'un conte tradicional, amb la intenció d'esbossar-hi, amb molta cautela, algunes relacions de parentiu, és un requisit indispensable per a comprendre i valorar amb precisió tant la dimensió tradicional com l'originalitat creativa d'alguns dels autors més significatius de la literatura exemplar. 


\section{Obres citades}

\section{I Remissió a les edicions de les obres més citades}

Canterbury tales: Benson ed. I988.

Elconde Lucanor: Serés ed. 1994.

Fèlix o Llibre de meravelles: Badia et al. ed. 2OII.

Kitāb al-mukhtārfì kaixf al-asrār: original, a Höglmeier ed. 2006; ací citat per una traducció catalana ad hoc d'Alba Vinyes Lasso.

Libro del cavallero Zifar: González ed. I983.

Novellino Borghini: Lo Nigro ed. 1963.

Tractat de les penes particulars d'infern: Gómez ed. 20I3b.

\subsection{Totes les obres citades}

Abrahams, Harold J., I984, "Al-Jawbari on false alchemists", Ambix 31/2, 84-88.

Babcock Folch-Pi, Willa, I967, “Ramon Lull's Felix and Chaucer's Canon's yeoman's tale”, Notes \& Queries 2I2, IO-II.

Badia, Lola, dir.; Bonillo, X.; Gisbert, E.; Lluch, M. ed., 2oII, Ramon Llull, Llibre de meravelles, vol. I, Llibres I-VII, Barcelona-Palma, Publicacions de l'Abadia de Montserrat - Patronat Ramon Llull (Nova Edició de les Obres de Ramon Llull, ro).

Benson, Larry D., ed., I988, The riverside Chaucer, Oxford, Oxford University Press.

Cacho Blecua, Juan Manuel, I996, "Los problemas del Zifar”, dins Libro del caballero Zifar. Códice de París. Estudios, Francisco Rico dir., Rafael Ramos ed., Barcelona, Moleiro, 55-94.

Carreras Artau, T.; Carreras Artau, J., I972, "Dues notes sobre el lul-lisme trecentista”, Estudios Lulianos I6, 23I-39.

Cingolani, Stefano, I990-9I, “'Nos en leyr tales libros trobemos plazer e recreation’: l'estudi sobre la difusió de la literatura d'entreteniment a Catalunya els segles XIV i Xv", Llengua \& Literatura 4, 39-I27.

Cooper, Helen, 1996, Oxford guides to Chaucer: The Canterbury tales, 2a ed., Oxford, Oxford University Press.

Collette, Carolyn P.; DiMarco, Vincent, 2005, "The canon's yeoman's tale", dins Sources and analogues of The Canterbury tales, vol. 2, Robert M. Correale, Mary Hamel ed., Cambridge, D. S. Brewer, 755-47.

Corbett, James, 195I, Catalogue des manuscrits alchimiques latins, 2, Manuscrits des bibliothèques publiques des départements français antérieurs au XVIf siècle, Bruxelles, Union Académique 
Internationale.

Crisciani, Chiara, 2002a, "Alchimia e potere: presenze francescane (secoli XIII-XIV)", dins I francescani e la politica. Atti del Convegno internazionale di studio (Palermo 3-7 Dicembre 2002), vol. 2, Alessandro Musco ed., Palermo, Biblioteca Francescana - Officina di Studi Medievali, 22335 .

Crisciani, Chiara, ed., 2002b, Il Papa e l'alchimia: Felice V, Guglielmo Fabri e l'elixir, Roma, Viella.

Delcorno, Carlo, I983, "Dante e l'exemplum medievale", Lettere Italiane 35/I, 3-28.

Devoto, Daniel, 1972, Introducción al estudio de don Juan Manuel y en particular de "El conde Lucanor": una bibliografía, Madrid, Castalia.

Duncan, Edgar H., I968, “The literature of alchemy and Chaucer’s Canon's yeoman's tale: framework, theme, and characters", Speculum 43/4, 633-56.

[Duval, Robert,] I56I, Verae alchemiae artisque metallicae, citra aenigmata, doctrina, Basileae.

Folena, Gianfranco, ed., I953, Motti e facezie del Piovano Arlotto, Milano-Napoli, Ricciardi.

Fradejas Lebrero, José, 20oI, "La alquimia en la narrativa medieval: el alquimista fabricante de oro", Garoza I, IO7-32.

Gómez, Francesc J., 2005, "De l'Inferno de Dante a l’infern teològic del framenor castelloní Joan Pasqual”, Mot So Razo 4, 2I-33

Gómez, Francesc J., 20Iza, "Joan Pasqual OFM i la seva adaptació teològica de l'Inferno", Medievalia I6/2, 55 bis-63bis [també dins Translatio. Transition, mobility and change in medieval culture, Joan Curbet, Alberto Reche ed., Santa Coloma de Queralt, Obrador Edèndum, 20I4, pp. 73-8I].

Gómez, Francesc J., 20I3b, El "Tractat de les penes particulars d'infern" de Joan Pasqual: estudi i edició crítica, tesi doctoral, Girona, Universitat de Girona.

Gómez, Francesc J., 2OI5, “Dante e Pietro Alighieri nell'opera teologica del minorita catalano Joan Pasqual”, Studi Danteschioo, en premsa.

González, Cristina, ed., I983, Libro del Caballero Zifar, Madrid, Cátedra (Letras Hispánicas, I9I).

Gual, Victòria, trad., I998, Geoffrey Chaucer, Contes de Canterbury, Barcelona, Quaderns Crema.

Höglmeier, Manuela, ed., 20o6, Al-Ǧawbarī und sein Kaśf al-asrār: ein Sittenbild des Gauners im arabisch-islamischen Mittelalter (7./13. Jahrhundert): Einführung, Edition und Kommentar, Berlin: Klaus Schwarz (Islamkundliche Untersuchungen, 267).

Hughes, Jonathan, 2012, The rise of alchemy in fourteenth-century England: Plantagenet kings and the search for the Philosopher's Stone, Londres, Continuum.

Khawam, René R., trad., I979-80, 'Abd al-Rahmāne Al-Djawbarī, Le voile arraché: l'autre visage de l'Islam, Paris, Phébus, 2 vols.

Linden, S. J., I996, “CConcluden everemore amy's': Chaucer and the medieval heritage of alchemical satire", dins el seu Darke hierogliphicks: alchemy in English literature from Chaucer to the Restoration, Lexington, University Press of Kentucky, I996, 37-6r i 304-308.

Lo Nigro, Sebastiano, ed., I963, Novellino e conti del Duecento, Torino, UTET.

López Pérez, Miguel, 2OIO-I3, "El fraude del alquimista en la literatura. Parte I: Orígenes del relato: 
de los orígenes a Al-Jawbari (65I-H. г240)", Azogue 7, I5-43.

Manget, Jean Jacques, I702, Bibliotheca chemica curiosa, Genevae, 2 vols.

Marsan, Rameline E., I974, Itinéraire espagnol du conte médieval (VIII-XV siècles), Paris, Klinksieck.

Maugin de Richebourg, Jean, 1740-54, Bibliothèque des philosophes chimiques. Nouvelle édition, Paris, 4 vols. (Ia ed. I672-73).

Migliorino, Francesco, 198I, "Alchimia lecita e illecita nel Trecento", Quaderni Medievali II, 6-4I.

Papanti, G. [Romagnoli, Gaetano], ed., I968, Facezie e motti dei sec. XV e XVI ined., Bologna, Commissione per i Testi di Lingua (Ia ed. I874).

Patai, Raphael, 1994, The Jewish alchemists: a history and source book, Princeton, Princeton University Press.

Pereira, Michela, I987, “La leggenda di Lullo alchimista”, Estudios Lulianos 77, I45-63.

Pereira, Michela, ed., I989, The alchemical corpus attributed to Raymond Lull, London, Warburg Institute-University of London.

Pereira, Michela; Spaggiari, Barbara, ed., I999, Il Testamentum alchemico attribuito a Raimondo Lullo: edizione del testo latino e catalano dal manoscritto Oxford, Corpus Christi College, 244, Firenze, Sismel-Edizione del Galluzo.

Principe, Lawrence M., 20I3, The secrets of alchemy, Chicago-London, The University of Chicago.

Puybusque, Adolphe de, 1854, Le comte Lucanor: apologues et fabliaux du XIV' siècle, Paris.

Rodríguez Guerrero, José, 2009, "Un origen griego para la alquimia y otras historias filosofales en el Baldo castellano de I542", Literary alchemy: representing early modern science = The Colorado Review of Hispanic Studies 7 (Fall), 33-48.

Rubió i Lluch, Antoni, I908-2I, Documents per l'història de la cultura catalana mig-eval, Barcelona, Institut d'Estudis Catalans, 2 vols.

Serés, Guillermo, ed., 1994, Don Juan Manuel, El conde Lucanor, estudio preliminar de Germán Orduna, Barcelona, Crítica (Biblioteca Clásica, 6).

Serrano Reyes, Jesús L., 1996, Didactismo y moralismo en Geoffrey Chaucer y don Juan Manuel: un estudio comparativo textual, Córdoba, Universidad de Córdoba.

Smalley, Beryl, I96o, English friars and Antiquity in the early fourteenth century, Oxford, B. Blackwell.

Thompson, Stith, I955-58, Motif-index offolk literature, Copenhagen, Rosenkilde \& Bagger, 6 vols. http://www.ruthenia.ru/folklore/thompson/index.htm (checked I4-o6-20I5).

Tubach, Frederic C., I98I, Index Exemplorum: A handbook of medieval religious tales, Alan Dundes, Lauri Honko, Matti Kuusi, Kurt Ranke, Anna Birgitta Rooth ed., Helsinki, Suomalainen Tiedeakatemia / Academia Scientiarum Fennica (Fellow Folklore Communications, LXXXVI, 204) (ra ed. r969).

Wagner, Ch. Ph., I9O3, "The sources of El cavallero Zifar", Revue Hispanique IO, 5-IO4.

Wesselski, A., ed., I9Iо, Die Schwänke und Schnurren des Pfarrers Arlotto, Berlin, Alexander Duncker, 2 vols. 